\title{
The Effect of Ethnocentrism on Product Evaluation and Purchase Intention: The Case of Extra Virgin Olive Oil (EVOO)
}

\author{
Juan Jose Blazquez-Resino ${ }^{1, *} \mathbb{( D}$, Santiago Gutierrez-Broncano ${ }^{1}\left(\mathbb{D}\right.$, Pedro Jimenez-Estevez $^{2}$ \\ and Israel Roberto Perez-Jimenez ${ }^{3}$
}

1 Department of Business Administration, Faculty of Social Science, Castilla-La Mancha University, Av. Real Fabrica de Seda, Talavera de la Reina, 45600 Toledo, Spain; Santiago.Gutierrez@uclm.es

2 Department of Business Administration, Faculty of Legal and Social Sciences, Castilla-La Mancha University, San Pedro Martir, 45001 Toledo, Spain; Pedro.JEstevez@uclm.es

3 Department of Spanish and International Economics, Econometrics and Economic History and Institutions, Faculty of Legal and Social Sciences, Castilla-La Mancha University, San Pedro Martir, 45001 Toledo, Spain; IRoberto.Perez@uclm.es

* Correspondence: Juan.Blazquez@uclm.es; Tel.: +34-925-721-010

\section{check for} updates

Citation: Blazquez-Resino, J.J.; Gutierrez-Broncano, S.

Jimenez-Estevez, P.; Perez-Jimenez, I.R. The Effect of Ethnocentrism on Product Evaluation and Purchase Intention: The Case of Extra Virgin Olive Oil (EVOO). Sustainability 2021, 13, 4744. https://doi.org/10.3390/ su13094744

Academic Editors: Luigi Roselli and Maria Pilar Martinez-Ruiz

Received: 8 February 2021

Accepted: 21 April 2021

Published: 23 April 2021

Publisher's Note: MDPI stays neutral with regard to jurisdictional claims in published maps and institutional affiliations.

Copyright: (c) 2021 by the authors. Licensee MDPI, Basel, Switzerland. This article is an open access article distributed under the terms and conditions of the Creative Commons Attribution (CC BY) license (https:// creativecommons.org/licenses/by/ $4.0 /)$.

\begin{abstract}
This study is framed within the concept of sustainability of local foods such as extra virgin olive oil (EVOO) and considers the effects of country of origin (COO) and ethnocentrism as relevant factors in decision making about product choice. Our work contributes to the literature regarding the food industry with the main objective of investigating how consumer ethnocentrism may affect not only behavioral intention but also the perception of the quality of the EVOO. The authors of the present paper developed this line of research via a review of the existing literature, leading to the elaboration of the conceptual model proposed in this paper. The research was developed through a laboratory experiment and the modeling of consumer behavior, raising a series of hypotheses, which were contrasted following the different analyses conducted on the data. Results were obtained on factors such as the differences in evaluation according to label type, the effect of ethnocentrism on perception and purchase intention, and structural knowledge of the weight of the different variables that influence this decision making. Several guidelines and conclusions are derived from these results, which refer to the use of COO information as well as the satisfaction of consumer ethnocentrism. Understanding the role played by consumer ethnocentrism in the evaluation of food products in accordance with their origin may yield useful information for local food producers.
\end{abstract}

Keywords: sustainable food; EVOO; country of origin; consumer ethnocentrism; quality attributes; purchase intention

\section{Introduction}

Sustainability is defined as the ability to preserve a given set of environmental, economic, and social conditions for an indefinite quantity of time [1]. Although environmental objectives are routinely considered, the dimensions of the economy and society have been added to form the "three pillars of sustainability" [2]. The economic conditions necessary for sustainability include supporting the viability of local economies and the ability to improve the quality of life of their respective producers [3], while the social aspect relates to aspects associated with consumption, such as supporting the local economy or paying fair prices, and plays an important role in explaining consumers' motivations for consuming local products [4].

Local food may be categorized as "sustainably produced food", since it reflects two components of sustainability [4]: a social component related to the integration of support from the agri-food sector with the priorities and needs of citizens and an environmental component related to the sustainable use and management of natural resources. Bianchi and Mortimer [5] (p. 2284) define local foods as meals produced, retailed, and consumed 
in a specific geographical area. However, the "local" concept is not only determined by political-administrative boundaries, but also relates to production methods [6], food traditions, or the symbolic and cultural value of a food product [7]. Therefore, a local product is one which is produced and consumed within a certain geographical proximity and which offers consumers one of the benefits related to the product's perceived superiority. Extra virgin olive oil (EVOO) can be considered a local as well as a localist product, in that its consumption is marked by the local culture of the Mediterranean region. EVOO is the superior olive oil quality category. It is obtained directly from olives by a mechanical extraction process, which is a chemical-free process, involving only pressure; thus, the oil is characterized by a low natural level of acidity and perfect flavor and aroma and is free from defects.

The olive oil sector has a special social, economic, and environmental importance within Mediterranean agri-food systems. Due to its agro-climatic conditions, four countries bordering the Mediterranean (Spain, Tunisia, Italy, and Greece) account for $60 \%$ of the world's olive grove area [8]. In the last 15 years, there has been an extraordinary expansion of the olive grove area, such that production has expanded from occurring in 46 countries to 64. Specifically, the total production increased from 1.45 million tons in the 1990-1991 campaign to 3.19 million tons in the 2018-2019 campaign, which represents an increase of $120 \%$. In addition, due to the increase in popularity associated with its benefits, the consumption of olive oil has grown considerably in many countries, including Australia, Brazil, Canada, Japan, and the United States [9]. The increased trade associated with globalization has made consumers' purchasing decisions more complex; many consumers must decide between domestic products and imported alternatives [10]. It is thus necessary to explore consumers' behavior toward EVOO consumption and understand their attitudes toward domestic and foreign products in the context of globalized markets [11].

In recent decades, marketing literature has begun to pay attention to the effects produced by country of origin (COO), also referred to as "made in" [12], on consumer food choices [13]. The COO effect can be defined as the impact, either positive or negative, that local production has on consumers' choice behavior, through their perception and evaluation of products $[14,15]$. Therefore, $\mathrm{COO}$ is considered as an extrinsic cue for consumers, signaling the overall quality of a product $[16,17]$, and may influence product evaluation, purchase intention, and behavior (e.g., references [17-20]). However, the use of the COO effect as a single cue has been evaluated as insufficient [11]. Evidence shows that consumers see $\mathrm{COO}$ as an opportunity to display allegiance with food products of their own country [21]; that is, it is possible to recognize the superiority of foreign products based on the COO effect, yet people prefer to buy local products [13]. This feeling can be considered a reflection of consumer ethnocentrism (CE) [22], established as a personality trait [23] that represents the emotional dimension of purchasing behavior [24]. Previous research has established that $\mathrm{CE}$ can explain different aspects of buying behavior and attitudes toward imported versus domestic products [25], especially for food products (e.g., references $[11,26,27])$. Although both COO and CE have been widely studied separately, most research has not produced significant results regarding the relationship between consumer ethnocentrism and consumer behavior with respect to $\mathrm{COO}$ products, especially in the food market (see [13] for a review); some authors (e.g., reference [28]) consider it necessary to continue developing studies clarifying the link between the $\mathrm{COO}$ effect and CE.

On the other hand, it is important to consider that, in addition to extrinsic cues, such as image, price, or place of origin, consumers use intrinsic cues as a basis for evaluating the product. In fact, the $\mathrm{COO}$ effect refers to the expectations regarding a product's quality based on the country in which it was made [29]. Therefore, sensory qualities, such as taste, appearance, or smell are also fundamental aspects that affect and determine consumer behavior. However, to our knowledge, the studies that consider intrinsic variables to determine the effect of $\mathrm{COO}$ and ethnocentric consumers are quite limited $[11,30]$. 
Previous studies have concluded that the effect of ethnocentrism can vary significantly across different food product categories (e.g., references [13,22,31,32]). Considering that the organoleptic characteristics of EVOO (taste, color, etc.) are the factors of greatest importance, the main objective of this paper is to understand whether consumers' predisposition toward local products has a significant effect not only on the purchase intention of consumers but also on the perceived quality of an EVOO. Specifically, the paper aims, firstly, to determine whether CE has a significant effect on perception of the EVOO quality characteristics, depending on whether it is a local or foreign product; and secondly, if the level of ethnocentrism influences behavioral intention differently according to the $\mathrm{COO}$ of the EVOO. From a theoretical perspective, this study contributes to the literature on CE by deepening the knowledge about the effect not only on behavior but also on the perception and evaluation of food products.

The structure of the paper is as follows: firstly, a brief review of the literature is provided, leading to the development of the proposed conceptual model. Then, the materials and methods are described, followed by the presentation of the results. The paper ends with conclusions, limitations, implications, and future lines of research.

\section{Literature Review}

According to Nagashima [33] (p. 68), COO can be viewed as the image and reputation that business people and consumers attribute to the products of a specific country based on variables such as its representative products, national characteristics, economic background, history, and traditions. Henceforth, the influence that $\mathrm{COO}$ has on perceptions, attitudes, and behavior is defined as the $\mathrm{COO}$ effect or the place-of-origin effect. Papadopoulos and Heslop [15] (p. 404) define the COO effect as "a set of strengths and weaknesses linked to the place-of-origin that add or detract value from the product for consumers". Since the seminal work of Schooler [34], marketers and scholars have focused on understanding the importance that consumers attach to the information provided by the $\mathrm{COO}$ when evaluating a country's products and how this influence on consumer consumption impacts decisions. Bilkey and Nes [14] (p. 94) state that "country of origin does indeed influence buyer perceptions of the products involved". Therefore, the place of origin becomes a fundamental factor in determining consumer perception and, consequently, purchasing behavior [35], especially in the presence of unawareness [36].

However, although the $\mathrm{COO}$ effect has been extensively investigated in the literature (see $[14,17,36-39]$ for a review), attention given to the role played by the COO on consumer food choices is a more recent phenomenon [13,29,40-42]. As Pieniak et al. [43] note, there is a growing consumer interest in products of local or regional origin and in products that have a traditional character or image. It is possible to identify three lines of research with respect to the effect of $\mathrm{COO}$ information: the perception of superior product quality (e.g., references $[42,44,45])$; the perceptions, attitudes, and preferences of consumers (e.g., references $[19,20,46-49])$, and the intentions surrounding a purchase (e.g., references $[17,18,50])$.

Food COO labels have been introduced by different economic agents and private food companies with the aim of restoring consumer confidence via the reduction of information asymmetry $[4,9]$. In the European context, one of the most important elements of protection is implemented through the adoption of the EU quality labels: the Protected Designations of Origin (PDO) and the Protected Geographical Indications (PGI) (see [51] for a review on how these labels affect consumers). This regulatory framework focuses on the protection of geographical indications and designations of origin for agricultural products and foodstuffs, attesting the specific tradition and quality of food products and facilitating information flows between farmers, buyers, and consumers [52]. At the national level, it is also possible to adopt collective quality certifications aimed at protecting the quality specifications of local food production [53].

COO information is considered an extrinsic cue, as price, brand, or packaging [53] may influence product evaluation, perceived risk, purchase intention, and behavior [14]. 
However, the consumption of food is a very complex event, resulting from an interplay between cultural, economic, and social forces [5]. Verlegh and Steenkamp [17] establish that consumer preference according to $\mathrm{COO}$ has three main components: a cognitive signal, as it acts as an informative variable related to the attributes of a product, such as quality; an affective component, which can be considered as containing a symbolic and emotional meaning that determines the positive and negative feelings toward the products of a country; and finally, a normative component, which involves the social and personal norms of consumers, who may have a tendency to favor the local economy and national production. Therefore, origin labels are not only a proxy for quality attributes but can also be an indication of the value perceived by the consumer in relation to the product's authenticity or traditions associated with the country $[54,55]$.

However, the impact of the COO effect depends on both the country's image and the product category $[9,22,32,52,56]$. Each production region or specific product category can elicit positive, negative, or neutral responses in consumers' minds. There is an ongoing debate regarding the magnitude of the $\mathrm{COO}$ effect on consumers' product evaluations and the variables that might moderate that effect [57]. The analysis of consumer preferences for olive oil is a consolidated research field [58]. Since the initial research was conducted, most studies have specifically considered the $\mathrm{COO}$ within the buying criteria in producer and nonproducer countries (see $[40,59]$ for a review). In the case of EVOO, the importance of origin labels can be justified for two critical reasons [40]: because they are significantly related to the organoleptic characteristics and quality of the oil, and because olive oil exports have grown extensively in recent years. Many previous studies have concluded that $\mathrm{COO}$ is a fundamental element in consumer choice [58-60]. However, $\mathrm{COO}$ has relatively small importance compared to other attributes. Although previous studies have found that $\mathrm{COO}$ is a crucial factor (e.g., references [4,61-65]), other research has shown that $\mathrm{COO}$ was not among the main cues used by consumers when making purchasing decisions [40]. Recently, Tempesta and Vechiatto [41] found that, when a product that is considered to be of high quality is obtained in another region, the preference for the area of residence may be negated.

On the other hand, regarding the preference for different national origins of olive oil, most studies indicated that consumers show a positive home-country bias, i.e., they tend to perceive and evaluate domestic products more favorably. Studies carried out in Italy (e.g., references $[9,58,60,64,66-71])$ found that local consumers have a greater preference for the traditional production of their own country. Krystallis and Ness [62] found that geographical indications for olive oil are relevant cues for several consumer segments in Greece. Romo-Muñoz et al. [65] found that Chilean EVOO consumers prefer domestic olive oil over their Italian and Spanish counterparts. In a study by Al Ganideh and Good [72], consumers from Jordan, a developing nation, perceived their local olive oil to be better and of higher quality than olive oil sourced from developed countries such as Italy and Spain. In Spain, some studies have also been carried out to analyze the COO effect on local consumers' evaluation and preference for local olive oil [40,52,59,73-77]. Some authors consider that the feeling that a country's food products are superior can be seen as a reflection of CE (e.g., references [21,22,72]).

The term ethnocentrism was introduced by Sumner [78] as a sociological concept and understood as an individual's general inclination to feel pride in belonging to a group (ingroups) and to base their evaluations on the standards established by the group itself, ergo rejecting people considered to be culturally different (outside groups). More recent approaches consider ethnocentrism as part of human nature [79] that manifests itself in multiple social groups, specifically at the family, religious, or geographical level. Shimp and Sharma [80] applied this concept to the evaluation of products, referring to consumers' beliefs about the appropriateness and morality of purchasing products made abroad [81]. The authors developed the concept of consumer ethnocentrism (CE), which they define as "the beliefs held [ ... ] by consumers about the appropriateness, indeed morality, of purchasing foreign-made products", considering that "buying imported products is 
wrong because, in their opinion, it damages the national economy, causes the loss of jobs work and is clearly unpatriotic" [80] (p. 280). Within the same range of analysis, it is possible to establish preference for products originating from one's own country. According to Lusk et al. [21] (p. 285), CE "relates to how an individual's buying habits are influenced by loyalties toward their own countries and/or antipathy toward other countries". Therefore, we consider that CE supposes, on the one hand, rejecting the purchase of products manufactured in outside regions and, on the other, the tendency to prefer products originating from the place to which one belongs.

In the case of the food market (see $[13,82]$ for reviews), CE continues to represent one of the strongest import blockades and so could be considered an important factor to predict consumer attitudes and perceptions toward imported and foreign food products $[83,84]$. The background assumption is that food can be considered as a cultural element, and people do not eat the same food across different cultures [53]. CE represents the emotional dimension in the purchase behavior relating to local products [24], which is proposed to preserve the culture of the country, along with solidarity, loyalty, and survival of the group [85]. This sense of belonging felt by any individual [86] causes consumers with a high ethnocentric tendency to perceive a product derived from their ethnic or cultural group as inherently superior [87] and increases their purchase intention. In contrast, nonethnocentric consumers will value products on their own merits, regardless of where they are manufactured.

However, some studies conclude that the domestic country bias due to $\mathrm{CE}$ can be country-specific $[53,56,83]$ as well as product-specific [22]. Thus, consumers may consider products of specific categories as having better quality, lower price, and so on, than others with differing origins $[88,89]$. In the case of the olive sector, the empirical applications of CE are limited. Romo-Muñoz et al. [65] identified 78 studies that focus on olive oil consumer preferences, with a smaller number of studies including $C E$ as a study variable (e.g., references $[72,86,90])$. In the case of Spain, some studies have focused on the concept of consumer ethnocentrism in products such as wine [6,91] or ethnic food $[92,93]$, but very few studies have applied this to olive oil [94].

Although CE is closely linked to COO, they represent two distinct terms [13]. Huddleston et al. [47] establish that there is a clear difference, since COO is an attribute of the product and is not a social indicator, while CE is a biased preference toward one's own country [24]. Multiple studies have studied the $\mathrm{COO}$ and CE concepts separately; however, the number of investigations examining the relationship between these two concepts is limited $[5,6,22,23,25,30,31,56,95,96]$.

\section{Development of the Empirical Model}

While the literature has begun to pay attention to the role of $\mathrm{CE}$ in consumption behavior, the effect on food consumption remains under-researched [5]. Considering that both the $\mathrm{COO}$ and $\mathrm{CE}$ effect depend on the product category and market, the main purpose of this study was to analyze the impact of ethnocentrism and COO on overall consumer perception and the intention to buy and consume EVOO.

Previous studies considered CE as an antecedent variable of the COO effect $[10,31,80,81,97,98]$. For example, Shankarmahesh [84] and Pharr [99] conducted comprehensive reviews of the CE and $\mathrm{COO}$ concepts, respectively, both reaching the conclusion that $\mathrm{CE}$ is a variable that precedes the COO. On the other hand, the role that $\mathrm{CE}$ exercises on consumer behavior has been widely studied. Both $\mathrm{CE}$ studies and those conducted from the $\mathrm{COO}$ point of view conclude that consumers prefer to purchase products from their own countries or regions. Although some studies conclude that $\mathrm{CE}$ is not always related to the actual purchase of these local food products [6] and fail to find a significant relationship between consumer ethnocentric tendencies and their choice to buy local food products [53,72], most previous studies establish that ethnocentrism is an antecedent of the purchasing behavior of local products (e.g., references [5,16,25,31,72,95,100-102]).

Kavak and Gumuslouglo [100] analyzed the Turkish food market, finding that, as the ethnocentrism level increased, so did the intention to purchase domestic food. Qing et al. [101] 
found that $\mathrm{CE}$ had a significant and positive influence on Chinese consumers' purchase attitudes toward domestic fresh fruit. Moreover, Orth and Firbasová [25] discovered that the CE level can successfully predict individuals' evaluations and preferences toward Czechmade yogurt. Conducting their study in the US, Lewis and Grebitus [95] discovered that more ethnocentric individuals and individuals who were more pessimistic about food safety were more likely to support COO for sugar and sugar in soft drinks. Al Ganidhes and Good [72] found that Jordanian consumers appear to be strongly ethnocentric toward purchasing local olive oil, which influences and shapes their food purchasing intention of local food. Urbonavičius et al. [102] analyzed how CE, which relates to the attention paid to the $\mathrm{COO}$ of the product, also influences decisions to purchase organic food items in four product categories: vegetables, meat, milk, and bakery products. Balabanis and Diamantopoulos [22] reached the conclusion that, overall, $\mathrm{CE}$ is a more consistent predictor of preferences for domestic products rather than for foreign products. Therefore, it is stated that:

Hypothesis 1 (H1). The consumer's ethnocentrism positively affects their Behavioral Intention toward purchasing local EVOO.

On the other hand, previous studies examining the relationship between $\mathrm{COO}$ and CE have shown that ethnocentrism is strongly related to consumer product evaluation for domestic food products [25,47] and perceived quality [31,103]. CE is, thus, an explaining factor for the domestic country bias in product perception. For example, Orth and Firbasová [25] identified CE as a strong predictor of the preferences for Czech-made yogurt among Czech consumers. In a study on consumer purchasing behavior of onions conducted in four different countries, Ehmke et al. [104] found that consumers perceived it as a positive attribute when the $\mathrm{COO}$ of the product was their own country.

It appears that consumers use product origin as an attribute related to its quality, either alone or in combination with other attributes [83]. For example, Caporale et al. [60] established that information on product origin affects local consumers' expectations regarding specific sensory attributes. Product information cues can be categorized into extrinsic cues, which are product-related attributes that are not part of the physical products, such as $\mathrm{COO}$, price, and brand, and intrinsic cues, which are an inseparable part of physical products, such as product shape, texture, and smell. Olson [105] states that intrinsic cues are more effective than extrinsic cues in product evaluation, because an objective evaluation of a product depends on direct experiences of the quality of a country's products [106]. In food products, demand depends on expected quality, a key element in determining consumers' quality expectations [107] and which can be perceived during consumption via factors such as taste, smell, tenderness, taste, and appearance.

Although it does not always seem rational, ethnocentric consumers are motivated to favor domestic products, because they believe it is good, desirable, appropriate, in short, moral, to buy these products. However, ethnocentric consumers may prefer domestic products not only because they believe it is appropriate from an economic or moral point of view but also because they are convinced that it is in their own place of origin that food of superior quality is produced [81]. In this way, ethnocentric consumers tend to have more favorable attitudes toward the products produced in their own country and overestimate the quality of domestic products. Previous studies have concluded that CE not only influences domestic shopping behavior [80] but also is positively related to both consumer judgments about food quality attributes, such as taste, nutritional value, or appearance [10,108]. Chryssochoidis et al. [31] found that Greek consumers with higher ethnocentric tendencies evaluated Greek products more favorably than less ethnocentric Greek consumers.

Despite the relationship between CE and the perception of product quality, very few studies have tried to determine the direct relationship between both concepts. Harcar and Kaynak [30] attempted to measure the impact of COO and ethnocentrism on American university students' taste perception and preferences to buy and consume labeled or unlabeled foreign soft drink products. The results support the notion that perceived 
overall quality assessment is, to a greater extent, based on consumers' ethnocentrism levels. However, without a COO, consumers do not appear to perceive a significant link between overall product quality, taste, intention to buy, and perceived health risk. Most recently, Basfirinci and Cilingir [11] examined the effect of COO and CE on consumers' taste perceptions of three different "made in" chocolate products. The results verified that CE does not have a significant main effect on taste perception and purchase intention of the product. However, when it was added to the model as an interaction term, the model showed a significant effect on both taste perception and purchase intention.

The domestic country bias due to ethnocentrism is product-specific [22]. EVOO is a complex good [109], and the perception of its quality depends on other intrinsic cues in addition to taste, such as color, smell, or texture. Some studies have conducted sensory analysis $[60,61]$, concluding that olive oil taste and color were considered two of the attributes that most influenced consumer perception (e.g., references [52,73]). Consequently, we propose the second hypothesis as follows:

Hypothesis 2 (H2). The consumer's ethnocentrism positively affects the Perceived Quality of local EVOO.

As CE predominantly has a positive influence on consumers' attitude and behavior toward local products, it is possible to establish that in the same way a rejection of imported products can be determined $[81,83]$. In this way, according to the definition of Shimp and Sharma [80], CE is based on an attitude of rejection toward purchasing foreign-made products. Since consumers with ethnocentric tendencies prefer the products of their own country, they are expected to make a biased evaluation of foreign products [12]. This previous research revealed impressive evidence regarding the determining effect on the prediction of consumers' attitude, perception, and evaluation of foreign products (e.g., references $[13,21,22,25,31,95])$.

It is possible to affirm that CE has a significant negative effect on the intention to purchase foreign products. The literature includes studies that support significant evidence showing that CE promotes reluctance to buy foreign products. Ricci et al. [53] (2019) investigated the barriers affecting the consumption of Italian products sold in the German market, concluding that ethnocentric tendencies prevent consumers from shopping for Italian food products. More recently, Kilders et al. [13] analyzed CE in Nigeria, finding that $C E$ is negatively associated with the purchase frequency of imported produce and poultry. On the other hand, an ethnocentric consumer might acknowledge the superiority of a foreign product over a domestic one based on its $\mathrm{COO}$ effect but still prefer the domestic one, accentuating the positive aspects of domestic products [24]. Balahabanis and Diamantopoulos [22] found that consumers preferred domestic food products and that $\mathrm{CE}$ is a barrier for purchasing food products from other countries. Chryssochoidis et al. [31] (2007) evaluated the level of CE in the Greek food market, comparing local and foreign beer, ham, and yellow cheese. They showed that ethnocentrism affects not only consumer beliefs, but also the way the perceived quality of domestic and foreign products was evaluated. Therefore, we propose two new hypotheses:

Hypothesis 3a (H3a). The consumer's ethnocentrism negatively affects their Behavioral Intention toward purchasing foreign EVOO.

Hypothesis $\mathbf{3 b} \mathbf{b} \mathbf{H} \mathbf{3} \mathbf{b})$. The consumer's ethnocentrism negatively affects the Perceived Quality of foreign EVOO.

The conceptual model presented in Figure 1 is based on the frameworks proposed: 


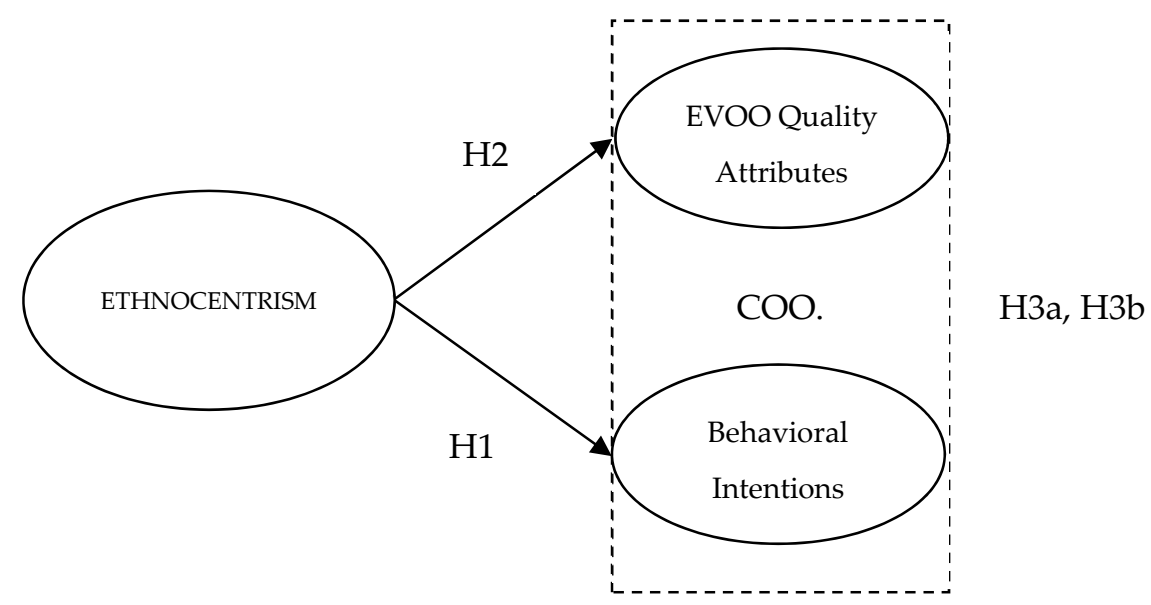

Figure 1. Empirical Model.

\section{Materials and Methods}

To achieve the aim of this paper, the present investigation was conducted using a laboratory experiment. This type of test is conducted in an artificial setting, where the necessary conditions are established to obtain the results according to the study design. EVOO was chosen due to being the type of olive oil with a worldwide image of quality and healthiness. EVOO plays an important role as a typical example of Mediterranean production, strongly affected by the origin of its raw material alongside intrinsic attributes, such as organoleptic qualities. In addition, previous papers have found significant differences in consumer evaluation according to the type of olive oil [64,91].

In the research design, $\mathrm{COO}$ was a manipulated variable, whereas $\mathrm{CE}, \mathrm{EVOO}$ Quality Attributes, and Behavioral Intention were measured variables. For the development of the experimental manipulation based on COO, two bottles with the same EVOO but with different labels were presented. The EVOO used was chosen by an olive oil expert from different high-quality EVOO alternatives in the Spanish market. The labels differentiated two countries of origin: one as produced and packaged in Spain and the other originating in Italy. The choice of the Spanish label, in addition to being the same nationality as the members of the experimental sample, is due to the olive oil sector being a strategic industry in the country: Spain is the world's leading producer and exporter of olive oil, in general, and EVOO, in particular. The choice of Italy is due to two fundamental reasons: it is the second main producer and exporter of olive oil worldwide, and it is the main destination for Spanish EVOO exports, with approximately 35\% of Spanish olive oil exported to Italy. There is also a strong link between the country and the product category worldwide [110], since olive oil is a basic element of the Italian gastronomic tradition. Different studies have carried out studies comparing the two countries. Menapace et al. [9] found that Italianorigin olive oil was preferred to that of Spanish origin and that it affected the willingness to pay among Canadian consumers. Boncinelli et al. [67] concluded that Italian consumers have a greater preference for traditional production than for olive oil from Spain.

To prevent the container used from having a determining effect on the participants [111,112], both bottles were made of glass and had the same design. Given that the commercial brand is an important attribute that can affect consumer choice [113,114], the labels consisted of two new brands created for the study and were, therefore, unknown to the general consumer, ensuring that there was no determinant effect of brand on consumer perception. Furthermore, in the analysis of the literature, it was found that various sociodemographic variables affect the ethnocentric tendencies of the consumer. Concerning age, younger consumers have lower levels of ethnocentric tendencies than older consumers (e.g., references $[25,72,86])$. Furthermore, previous studies (e.g., references $[31,62,82]$ ) have conducted their research on young people. Therefore, young people completing their first university courses and preuniversity students were enrolled for the present study. 
To carry out the contrast of the hypotheses, the study was carried out using a structural equations model (SEM). The model was empirically analyzed using partial least squares structural equation modeling (PLS-SEM), because it was a suitable technique due to its predictive capacity $[115,116]$. It is considered the most developed and general system among estimators based on variance for modeling structural equations and is applied in a wide range of disciplines. The PLS-SEM model was computed using the Smart PLS 3.0 statistical software application [117]. The multigroup analysis was then conducted using MICOM to study the invariance, and the partial least squares multigroup analysis (PLS-MGA) and permutation test were applied to analyze the group differences.

\subsection{Data Collection}

The experiment was conducted in a room equipped for the development of tasting tests. Once the presentation of the EVOO bottles had been completed and the instructions on how to perform the tasting had been provided, the EVOO was poured into a small tasting deep plate coded with a three-digit number corresponding to each of the two labels. Along with the EVOO, white bread cut into pieces was provided, the size of which was assessed so that everyone tasted the same amount of oil. The dishes were distributed among the participants of the session to carry out the tasting. Upon completion of the tasting, consumers filled out a survey that assessed the EVOO quality attributes and behavioral intention regarding the oil they had just tasted and their level of ethnocentrism. In addition, they had to indicate their consumption and purchase habits about olive oil, and their demographic information was collected. The data collection was carried out between March and May 2017.

To control the process of assigning the elements and the effects that the so-called external or confounding variables could have on the results and to ensure that the results obtained were exclusively due to the experimental treatments, in each session, the participants were randomly assigned to one of the treatments. Furthermore, since the female gender is positively related to CE $[81,86,91,111]$, both groups were controlled for the same number of participants according to gender. Participants were separated, ensuring that they did not interact with or influence each other, but there were no separate room partitions. To try to hide the objective of the study, participants were recruited with the instruction that they had to evaluate the product of a new EVOO brand that wanted to obtain information on consumer perception and intention to buy.

\subsection{Questionnaire}

Participants' assessments of the different variables related to EVOO included in the study were obtained through a questionnaire consisting of four clearly differentiated parts:

- EVOO Quality Attributes. In this first section, each participant indicated their assessment of variables related to the organoleptic characteristics of the EVOO. For the development of the measures, studies related to sensory analysis were used, the objective of which was to measure the assessment of the consumption of food products. An adaptation of the scales used by Delgado et al. [113] and Dekhili and d'Hauteville [118] was developed. The scale used to measure the organoleptic characteristics included six statements related to global opinion; the perception of the "Quality"; and the flavor regarding the "Color", "Taste", "Aroma", and "Texture" of the oil tested. The variables were measured using a seven-point Likert scale ranging from (1) "Strongly Disagree" to (7) "Strongly Agree".

- Behavioral Intention. This part of the questionnaire aimed to identify the intention of future consumer behavior regarding the olive oil tested. For the development of this scale, an adaptation of the studies by Caporale et al. [60] and Delgado and Guinard [61] was developed, establishing three study variables that determined the "Intention to Buy", "Intention to Consume in the Future", and "Intention to Recommend". These three variables were measured using a seven-point Likert scale ranging from (1) "Strongly Disagree" to (7) "Strongly Agree". 
- Ethnocentrism. The most widely used method to measure the ethnocentric tendencies of consumers in purchasing domestic products is the Consumer Ethnocentric Tendency Scale (CETSCALE) [80]. The CETSCALE is a multi-item scale that reflects a tendency to prefer home-country products to those of foreign origin [119]. Some studies have developed adaptations of the 17-item original scale, using measures composed of 10 items [56,103], 6 items [6,53,118], or 4 variables [5]. On the other hand, multiple studies (e.g., references $[81,91,120]$ ) use CETSCALE to determine the level of ethnocentrism of the consumer through the sum of the individual values achieved in each of the items. Based on the CETSCALE, all consumers are ethnocentric, and their ethnocentrism levels range from 10 to 50 on a 10-item, 5-point Likert scale CETSCALE and from 17 to 119 on a 17-item, 5-point Likert scale CETSCALE [72]. The level of ethnocentrism serves to establish direct segmentation between groups, taking the mean or median split as a reference, which allows the differentiation of consumers with a high or low level of ethnocentrism $[30,31,56,86]$. Few studies have applied ethnocentrism as a theoretical construct in the analysis model $[6,53,95]$, and even fewer studies have applied it as a dimension in structural equation modeling (SEM) [5]. Therefore, the present study used a nine-item adaptation of the CETSCALE (see Appendix A). Participants had to indicate their agreement with each of the statements that composed the scales on a seven-point Likert scale, ranging from (1) "Strongly Disagree" to (7) "Strongly Agree".

- Characteristics of the Consumer. Finally, the questionnaire included a series of variables on the characteristics related to the consumption of EVOO and the sociodemographic classification of the consumer. In the same way as in the studies by Caporale et al. [60] and Delgado and Guinard [61], to identify the characteristics of consumption of EVOO by the consumer, two measurement variables were included: "Frequency of Purchase" $(1=$ never; $2=$ less than once a year; $3=$ once or twice a year; $4=3-5$ times a year; $5=$ less than once a month; $6=$ once a month; $7=2-3$ times a month); and "Frequency of Consumption" ( $1=$ once a year or less; $2=$ less than once a month; $3=1-3$ times a month; $4=$ once a week; $5=2-4$ times a week; $6=$ every day; $7=$ more than once a day). The demographic classification questions included the variables "Gender", "Level of Education", and "Monthly Income".

\subsection{Sample}

Once the collected questionnaires had been analyzed and refined, the final sample comprised a total of 146 participants: 75 consumers carried out the EVOO tasting with a label identifying the product as Spanish, while 71 participants tasted the product identified as of Italian origin. A Chi-square test was conducted to determine whether the demographic and socio-economic characteristics of the two samples were stable in terms of certain demographic characteristics and whether the student sample would be deemed suitable for this research. If the sample had homogeneous subgroups, then it would be stable in terms of certain demographic characteristics. Given that the gender variable was controlled in the design of the experiment, the distribution of samples among subsets indicated no conspicuous biases regarding participants' gender [ $\left.\chi^{2}(1)=0.006, p=0.938>0.01\right]$. In the Spanish-label group, the gender ratio of the participants was $36.0 \%$ male to $64.0 \%$ female, while the sample for the Italian label was $63.4 \%$ female and $36.6 \%$ male. Another sociodemographic variable that has been shown to have a significant effect on CE is income level $[13,24,81,86,111]$. The composition of both groups by income level presented quite similar results (see Figure 2), and the Chi-square test confirmed no conspicuous biases $[\chi 2(1)=1.322, p=0.933>0.01]$. 


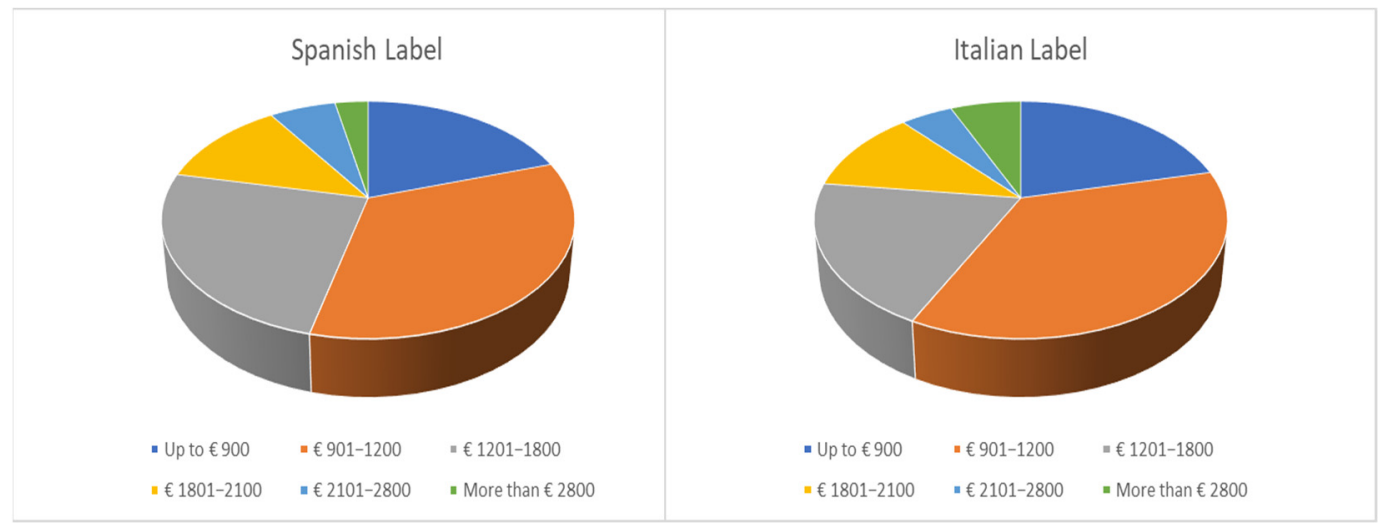

Figure 2. Composition of the sample by income level.

Another variable of interest is the frequency of consumption. The results were grouped according to daily, weekly, monthly, or higher-frequency consumption. The results achieved (see Figure 3 ) also showed homogeneity between both groups $[\chi 2(1)=2.807$, $p=0.833>0.01$ ] regarding the frequency of consumption and, therefore, the knowledge of the EVOO. In both groups, more than $85 \%$ of the sample indicated consuming EVOO on a daily or weekly basis.

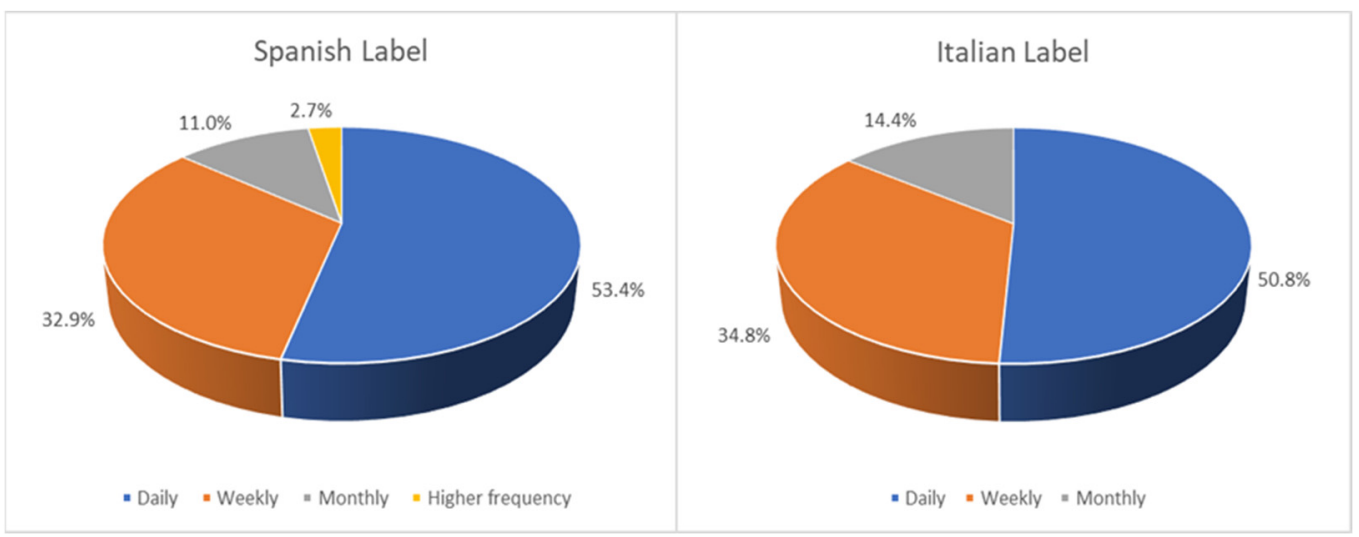

Figure 3. Composition of the sample. Frequency of use.

\section{Results}

This section presents the results obtained from the different analyses conducted on the data and which will enable the proposed study objectives to be achieved.

\subsection{Differences in Evaluation between Labels}

First, the measured ratings of each of the variables related to EVOO Quality Attributes and Behavioral Intention according to the $\mathrm{COO}$ label were analyzed. As can be seen in Figure 4, the results show that the EVOO with Spanish label is better valued in all the characteristics studied. In the case of Quality Attributes, the descriptive results show that the differences in the items "General Opinion" and "Taste" are more important than in the rest of the variables. The mean values in the variables related to Behavioral Intention are higher in the case of the sample of EVOO with a Spanish label than in EVOO with an Italian label. 


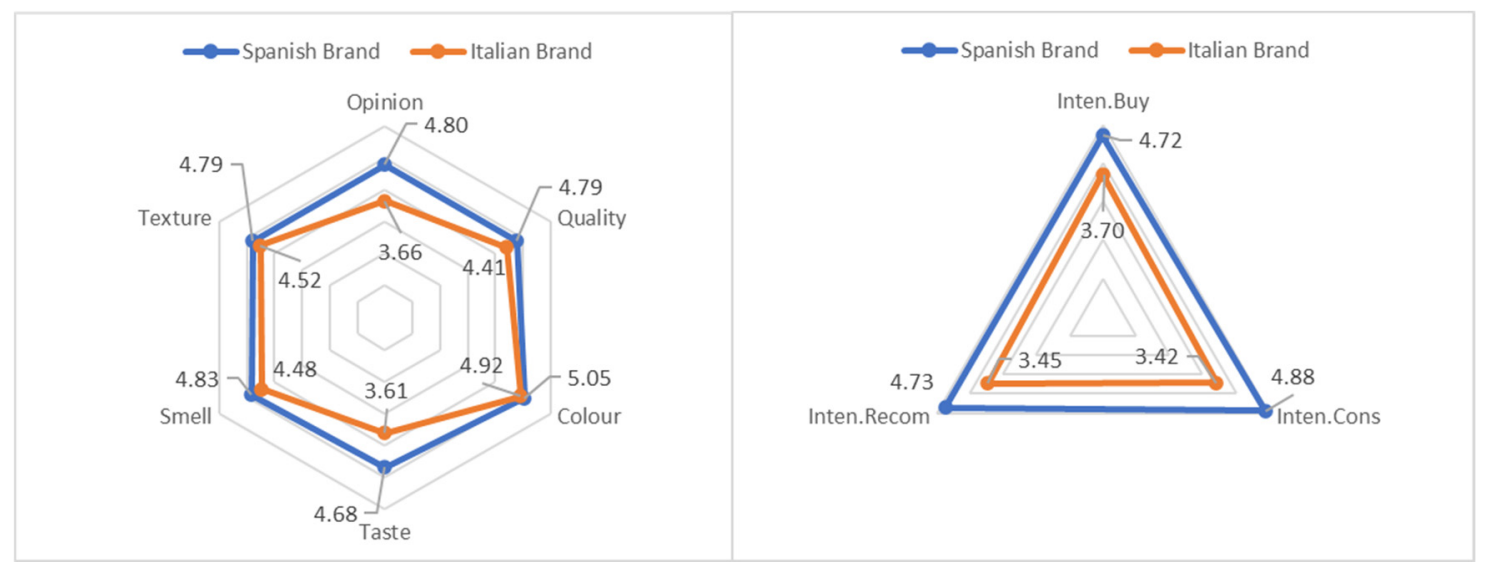

Figure 4. Differences in valuation between labels.

To determine which of the differences between the evaluations of the two dimensions are statistically significant, an analysis was carried out using the $t$-test statistic (see Table 1). As a parametric test, the $t$-test calculation requires homoscedasticity between the compared groups; therefore, the results of the Levene's Test were taken into consideration to select the $t$-values based on the equality or otherwise of variances between the groups.

Table 1. $t$-test of Mean Values, Depending on the COO Label.

\begin{tabular}{|c|c|c|c|c|c|c|c|c|c|}
\hline \multirow{2}{*}{ Item } & \multirow{2}{*}{ Label } & \multirow{2}{*}{ Mean } & \multirow{2}{*}{$\begin{array}{c}\text { Std. } \\
\text { Deviation }\end{array}$} & \multicolumn{2}{|c|}{$\begin{array}{c}\text { Levene's Test for } \\
\text { Equality of Variances }\end{array}$} & \multicolumn{4}{|c|}{$t$-Test for Equality of Means } \\
\hline & & & & $\mathbf{F}$ & Sig. & $t$ & $\begin{array}{c}\text { Sig. } \\
\text { (2-Tailed) }\end{array}$ & $\begin{array}{c}\text { Mean } \\
\text { Difference }\end{array}$ & $\begin{array}{l}\text { Std. Error } \\
\text { Difference }\end{array}$ \\
\hline \multirow{2}{*}{ Opinion } & Spanish & 4.80 & 1.197 & 13.326 & 0.000 & 4.670 & 0.000 & 1.138 & 0.244 \\
\hline & Italian & 3.66 & 1.715 & & & 4.626 & 0.000 & 1.138 & 0.246 \\
\hline \multirow{2}{*}{ Quality } & Spanish & 4.79 & 1.222 & 3.312 & 0.071 & 1.714 & 0.089 & 0.378 & 0.221 \\
\hline & Italian & 4.41 & 1.440 & & & 1.706 & 0.090 & 0.378 & 0.222 \\
\hline \multirow[b]{2}{*}{ Color } & Spanish & 5.05 & 1.184 & 0.369 & 0.544 & 0.701 & 0.485 & 0.138 & 0.197 \\
\hline & Italian & 4.92 & 1.192 & & & 0.701 & 0.485 & 0.138 & 0.197 \\
\hline \multirow{2}{*}{ Taste } & Spanish & 4.68 & 1.425 & 8.830 & 0.003 & 3.926 & 0.000 & 1.074 & 0.274 \\
\hline & Italian & 3.61 & 1.863 & & & 3.898 & 0.000 & 1.074 & 0.276 \\
\hline \multirow{2}{*}{ Smell } & Spanish & 4.83 & 1.167 & 0.542 & 0.463 & 1.763 & 0.080 & 0.348 & 0.197 \\
\hline & Italian & 4.48 & 1.217 & & & 1.761 & 0.080 & 0.348 & 0.198 \\
\hline \multirow[b]{2}{*}{ Texture } & Spanish & 4.79 & 1.177 & 4.055 & 0.046 & 1.236 & 0.218 & 0.266 & 0.215 \\
\hline & Italian & 4.52 & 1.413 & & & 1.230 & 0.221 & 0.266 & 0.216 \\
\hline Intent. & Spanish & 4.72 & 1.371 & 0.005 & 0.946 & 4.531 & 0.000 & 1.016 & 0.224 \\
\hline Buy & Italian & 3.70 & 1.335 & & & 4.535 & 0.000 & 1.016 & 0.224 \\
\hline Intent. & Spanish & 4.88 & 1.365 & 2.614 & 0.108 & 6.026 & 0.000 & 1.457 & 0.242 \\
\hline Consume & Italian & 3.42 & 1.555 & & & 6.004 & 0.000 & 1.457 & 0.243 \\
\hline Intent. & Spanish & 4.73 & 1.359 & 0.028 & 0.867 & 5.718 & 0.000 & 1.283 & 0.224 \\
\hline Recom. & Italian & 3.45 & 1.350 & & & 5.719 & 0.000 & 1.283 & 0.224 \\
\hline
\end{tabular}

The results show how the differences between the evaluations of the EVOO Quality Attributes according to the type of label reach significance only in the variables "Opinion" and "Taste". These results are adequate, considering the same type of EVOO was used in the study. These results show that both groups value the same type of oil in a similar way, with the differences in the less objective and more subjective variables being significant. However, in the case of Behavioral Intention, the results show that the consumer's intention to consume, purchase, and recommend EVOO with the label of their own country is significantly higher than in the case of EVOO from a different country. 


\subsection{Effect of Ethnocentrism on Perception and Purchase Intention}

As has been established at a theoretical level, it is important to consider the effect of the consumer's ethnocentrism to determine its influence on the evaluation of products according to their label. For this reason, the results were first determined according to the level of ethnocentrism displayed by young consumers. Table 2 shows the measured evaluations achieved by each of the groups in relation to the different variables that determine the ethnocentrism of the consumer.

Table 2. $t$-test of Mean Values of Ethnocentrism According to Analysis Items and COO Label.

\begin{tabular}{|c|c|c|c|c|c|c|c|c|c|}
\hline \multirow{2}{*}{ Item } & \multirow{2}{*}{ Label } & \multirow{2}{*}{ Mean } & \multirow{2}{*}{$\begin{array}{c}\text { Std. } \\
\text { Deviation }\end{array}$} & \multicolumn{2}{|c|}{$\begin{array}{c}\text { Levene's Test for } \\
\text { Equality of Variances }\end{array}$} & \multicolumn{4}{|c|}{$t$-Test for Equality of Means } \\
\hline & & & & $\mathbf{F}$ & Sig. & $t$ & $\begin{array}{c}\text { Sig. } \\
\text { (2-Tailed) }\end{array}$ & $\begin{array}{c}\text { Mean } \\
\text { Difference }\end{array}$ & $\begin{array}{l}\text { Std. Error } \\
\text { Difference }\end{array}$ \\
\hline \multirow{2}{*}{ Ethno1 } & Spanish & 1.77 & 1.158 & 0.213 & 0.645 & -0.078 & 0.938 & -0.015 & 0.197 \\
\hline & Italian & 1.79 & 1.218 & & & -0.078 & 0.938 & -0.015 & 0.197 \\
\hline \multirow[b]{2}{*}{ Ethno2 } & Spanish & 2.40 & 1.174 & 0.108 & 0.743 & -0.254 & 0.800 & -0.051 & 0.200 \\
\hline & Italian & 2.45 & 1.240 & & & -0.253 & 0.800 & -0.051 & 0.200 \\
\hline \multirow{2}{*}{ Ethno3 } & Spanish & 2.37 & 1.549 & 0.031 & 0.861 & -0.621 & 0.536 & -0.162 & 0.261 \\
\hline & Italian & 2.54 & 1.602 & & & -0.620 & 0.536 & -0.162 & 0.261 \\
\hline \multirow{2}{*}{ Ethno4 } & Spanish & 2.93 & 1.528 & 0.258 & 0.612 & -0.685 & 0.494 & -0.179 & 0.262 \\
\hline & Italian & 3.11 & 1.635 & & & -0.684 & 0.495 & -0.179 & 0.262 \\
\hline \multirow{2}{*}{ Ethno5 } & Spanish & 3.19 & 1.540 & 0.139 & 0.710 & -0.531 & 0.596 & -0.137 & 0.258 \\
\hline & Italian & 3.32 & 1.584 & & & -0.531 & 0.596 & -0.137 & 0.259 \\
\hline \multirow[b]{2}{*}{ Ethno6 } & Spanish & 3.15 & 1.430 & 2.440 & 0.120 & -0.923 & 0.357 & -0.234 & 0.253 \\
\hline & Italian & 3.38 & 1.625 & & & -0.920 & 0.359 & -0.234 & 0.254 \\
\hline \multirow{2}{*}{ Ethno7 } & Spanish & 1.92 & 1.112 & 0.480 & 0.489 & -0.573 & 0.568 & -0.108 & 0.189 \\
\hline & Italian & 2.03 & 1.171 & & & -0.572 & 0.568 & -0.108 & 0.189 \\
\hline \multirow[b]{2}{*}{ Ethno8 } & Spanish & 2.53 & 1.528 & 0.104 & 0.748 & -0.008 & 0.994 & -0.002 & 0.247 \\
\hline & Italian & 2.54 & 1.452 & & & -0.008 & 0.994 & -0.002 & 0.247 \\
\hline \multirow{2}{*}{ Ethno9 } & Spanish & 1.97 & 1.241 & 1.332 & 0.250 & -0.840 & 0.402 & -0.182 & 0.216 \\
\hline & Italian & 2.15 & 1.370 & & & -0.838 & 0.403 & -0.182 & 0.217 \\
\hline
\end{tabular}

According to the results of the $t$-test, there are no significant differences in the evaluations measured between both groups, which, again, allows us to establish the homogeneity of the groups. It is interesting to underline how the mean scores of the scale reveal that young people do not show an ethnocentric attitude, since none of the variables studied have values higher than the midpoint of the scale (3.5). In both groups, it is noteworthy that the variables Ethno4 (We should buy products made in Spain instead of allowing other countries to get rich at our expense), Ethno5 (It is best to always buy Spanish products), and Ethno6 (Spaniards should not buy foreign products that harm Spanish companies and cause unemployment) have higher mean values. Specifically, these variables show a certain feeling of patriotism, something that has been considered an antecedent of ethnocentrism $[80,121]$, in addition to concerns about keeping jobs. However, in those items that mention foreign products in a more direct way, the young people present the lowest evaluations of all the items used.

\subsubsection{Assessment of Measurement Model}

The PLS analysis proceeded according to a two-step approach: evaluation of the measurement model and evaluation of the structural model. The analysis of the measurement model required the study of the validity and reliability of the latent variables through their relationship with their associated measures. In PLS-SEM, this analysis of reflective indicators is performed through assessing individual and construct item reliability, convergent validity, and discriminant validity [122].

First, in assessing individual reliability, the loading of each indicator on its associated latent variable must be calculated and compared to a threshold. To be considered accept- 
able, the loading of each indicator should be higher than 0.5 , and its $t$-value should be significant. The results (see Table 3) show that the factorial loads of all the items on their constructs exceed the values established in the two analysis groups. Moreover, contrasting their $t$-values, the relationships are significant at 0.01. Cronbach's Alpha and composite reliability statistics support the construct reliability, since their values are higher than the cut-off value of 0.7 in all the constructs of the two models studied [123], which suggests satisfactory internal consistency.

Table 3. Measurement Model Analysis.

\begin{tabular}{|c|c|c|c|c|c|c|c|c|}
\hline \multirow[t]{2}{*}{ Construct/Item } & \multicolumn{2}{|c|}{ Loading } & \multicolumn{2}{|c|}{ Cronbach's Alpha } & \multicolumn{2}{|c|}{ Composite Reliability } & \multicolumn{2}{|c|}{ AVE } \\
\hline & Spanish & Italian & Spanish & Italian & Spanish & Italian & Spanish & Italian \\
\hline \multicolumn{9}{|l|}{ Ethnocentrism } \\
\hline Ethno1 & $0.684^{* *}$ & $0.695^{* *}$ & \multirow{9}{*}{0.887} & \multirow{9}{*}{0.891} & \multirow{9}{*}{0.907} & \multirow{9}{*}{0.911} & \multirow{9}{*}{0.521} & \multirow{9}{*}{0.534} \\
\hline Ethno2 & $0.751^{* *}$ & $0.785^{* *}$ & & & & & & \\
\hline Ethno3 & $0.784^{* *}$ & $0.720^{* *}$ & & & & & & \\
\hline Ethno4 & $0.794^{* *}$ & $0.819 * *$ & & & & & & \\
\hline Ethno5 & $0.810^{* *}$ & $0.649 * *$ & & & & & & \\
\hline Ethno6 & $0.719 * *$ & $0.783^{* *}$ & & & & & & \\
\hline Ethno7 & $0.617^{* *}$ & $0.706^{* *}$ & & & & & & \\
\hline Ethno8 & $0.637^{* *}$ & $0.649^{* *}$ & & & & & & \\
\hline Ethno9 & $0.675^{* *}$ & $0.753^{* *}$ & & & & & & \\
\hline \multirow{2}{*}{\multicolumn{9}{|c|}{$\begin{array}{c}\text { EVOO Quality } \\
\text { Attrib. }\end{array}$}} \\
\hline & & & & & & & & \\
\hline Opinion & $0.852 * *$ & $0.870^{* *}$ & \multirow{6}{*}{0.919} & \multirow{6}{*}{0.913} & \multirow{6}{*}{0.937} & \multirow{6}{*}{0.928} & \multirow{6}{*}{0.712} & \multirow{6}{*}{0.685} \\
\hline Quality & $0.879^{* *}$ & $0.883^{* *}$ & & & & & & \\
\hline Color & $0.796^{* *}$ & $0.815^{* *}$ & & & & & & \\
\hline Taste & $0.869 * *$ & $0.872^{* *}$ & & & & & & \\
\hline Aroma & $0.795^{* *}$ & $0.818^{* *}$ & & & & & & \\
\hline Texture & $0.867^{* *}$ & $0.692^{* *}$ & & & & & & \\
\hline \multirow{2}{*}{\multicolumn{9}{|c|}{$\begin{array}{l}\text { Behav. } \\
\text { Intention }\end{array}$}} \\
\hline & & & & & & & & \\
\hline Intent. Buy & $0.914^{* *}$ & $0.868^{* *}$ & \multirow[t]{3}{*}{0.891} & \multirow[t]{3}{*}{0.848} & \multirow[t]{3}{*}{0.929} & \multirow[t]{3}{*}{0.908} & \multirow[t]{3}{*}{0.813} & \multirow[t]{3}{*}{0.766} \\
\hline Intent. Cons. & $0.885^{* *}$ & $0.866^{* *}$ & & & & & & \\
\hline Intent. Recom. & $0.906^{* *}$ & $0.891^{* *}$ & & & & & & \\
\hline
\end{tabular}

We calculated the average variance extracted (AVE) to assess the convergent validity of both groups. The AVE of the constructs should be higher than 0.5 to be considered acceptable convergent validity [124]. All latent variables achieve convergent validity given that their AVE values surpass the 0.5 level (see Table 3).

Discriminant validity represents the degree to which the construct is empirically different from other constructs. Discriminant validity was tested through the FornellLarcker criterion and the HTMT index [125]. The obtained values for the Fornell-Larcker measure supports the convergent validity of the two models (see Table 4), because the square root of all AVE values exceeds the correlations between this composite and all other composites in the models [126]. Finally, the HTMT index shows that all reflective variables achieve discriminant validity in both models, since all values are less than 0.9 , and indicates that each of the two groups' models has acceptable discriminant validity. 
Table 4. Fornell-Larcker Criterion and HTMT Index.

\begin{tabular}{|c|c|c|c|c|c|c|c|}
\hline \multicolumn{8}{|c|}{ Fornell-Larcker Criterion } \\
\hline \multicolumn{4}{|c|}{ Spanish Brand } & \multicolumn{4}{|c|}{ Italian Brand } \\
\hline Ethno. & $\begin{array}{c}\text { Ethno. } \\
0.722\end{array}$ & E.Q.A. & B.I. & Ethno. & $\begin{array}{c}\text { Ethno. } \\
0.731\end{array}$ & E.Q.A. & B.I. \\
\hline E.Q.A. & 0.382 & 0.844 & & O.Q.A. & -0.296 & 0.828 & \\
\hline B.I. & 0.357 & 0.785 & 0.902 & B.I. & -0.348 & 0.772 & 0.875 \\
\hline \multicolumn{8}{|c|}{ HTMT Index } \\
\hline \multicolumn{4}{|c|}{ Spanish Brand } & \multicolumn{4}{|c|}{ Italian Brand } \\
\hline & Ethno. & O.Q.A. & B.I. & & Ethno. & E.Q.A. & B.I. \\
\hline $\begin{array}{l}\text { Ethno. } \\
\text { E.Q.A. }\end{array}$ & 0.374 & & & $\begin{array}{l}\text { Ethno. } \\
\text { O.Q.A. }\end{array}$ & 0.275 & & \\
\hline B.I. & 0.329 & 0.871 & & B.I. & 0.386 & 0.842 & \\
\hline
\end{tabular}

Note: Ethno = Etnocentrism; E.Q.A. = EVOO Quality Attributes; B.I. = Behavioral Intention.

\subsubsection{Assessment of Structural Model}

Once the reliability and validity of the measurement model were established, the structural model was evaluated through an analysis of the relationships between the different constructs raised in the study hypotheses. The values of the path coefficients $(\beta)$ and the explained variance $\left(R^{2}\right)$ were considered. Consistent with Hair et al. [124], bootstrapping (5000 resamples) was applied, which allowed evaluation of the statistical significance of the coefficients. The results obtained for the two models analyzed are shown in Figure 5.

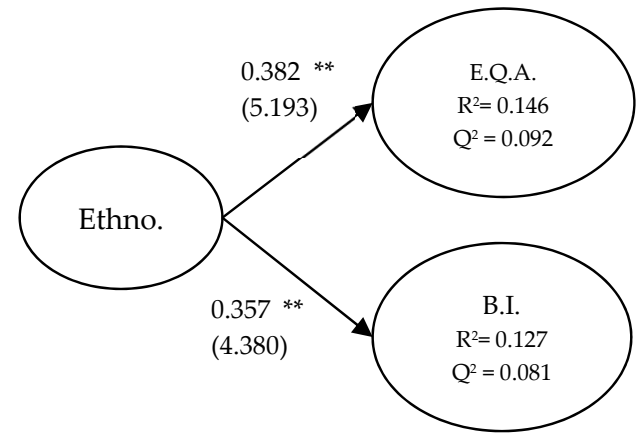

Spanish Label

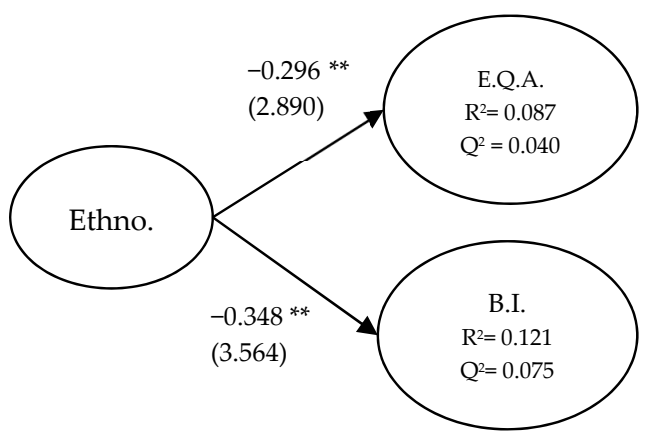

Italian Label

$$
{ }^{* *} p<0.01\left(t_{(0.01 ; 4999)}=2.576\right) .
$$

Figure 5. Differences between COO labels. Note: Ethno $=$ Etnocentrism; E.Q.A. $=$ EVOO Quality Attributes; B.I. $=$ Behavioral Intention.

The results of the structural model allow confirmation of $\mathrm{H} 1$ and $\mathrm{H} 2$, since significant and positive relationships are found between the ethnocentrism identified in young consumers and both the assessment of the attributes of the EVOO $(\beta=0.382, p<0.001)$ and Behavioral Intention $(\beta=0.357, p<0.001)$ for EVOO with the Spanish label. The results for EVOO with the Italian label reach significant values but, in this case, inversely. Although the level of explanation is not very high $\left(R^{2}=0.087\right)$, the CE achieves a significantly negative effect on the Quality Attributes perceived for Italian EVOO. More importantly, in the case of consumer behavioral intention, the level of explanation and effect size is very similar to that reached by the Spanish label but in a negative sense $(\beta=-0.348, p<0.001)$. Therefore, CE has an inverse effect on the intention to buy Italian EVOO. Additionally, to complete the validation of both models, Stone-Geisser's predictive relevance $\left(\mathrm{Q}^{2}\right)$ was 
developed. The results (see Figure 5) show that all values are positive, indicating that the model has predictive capacity for the estimation of values.

\subsubsection{Multigroup Analysis (MGA)}

The final analysis step involved studying the comparison effect and checking whether it was moderating. Two advanced analysis techniques to perform multigroup analysis (MGA) were used: Henseler's MGA [127] and the permutation test [128]. The multigroup analysis of partial least squares allows for evaluation of whether the groups of predefined data have significant differences in their estimations of specific parameters of the group. However, previously, prior to the MGA, Henseler et al. [129] advocated the calculation of the invariance of its measurements using the MICOM (Measurement Invariance Assessment) approach, which guarantees that the potential variations are a result of the moderating variable and not due to potential differences in the measurement models of each group.

The MICOM procedure provides a method for studying the invariance with a threestep process involving (a) assessment of the configured invariance (i.e., equal way of estimation); (b) establishment of compositional invariance assessment (i.e., equal indicator weights); and (c) assessment of equal means and variances. If configured and compositional invariance are established, partial measurement invariance is also established, allowing comparison of the path coefficient estimates across the groups.

Table 5 shows the results of the measurement invariance testing. In accordance with the MICOM procedure, the results show partial measurement invariance. Although this study did not assess the equality of the composite mean values and variances, configured invariance and compositional invariance were established, which is a requirement for comparing and interpreting the multigroup analysis. Thus, the results allowed for comparison of the path coefficients among the samples from male and female students.

Table 5. Results of Invariance Measurement Testing Using Permutation.

\begin{tabular}{|c|c|c|c|c|c|c|c|c|c|c|c|}
\hline \multirow[t]{2}{*}{ 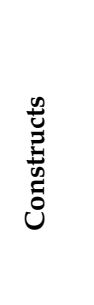 } & \multirow[t]{2}{*}{ 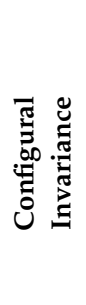 } & \multicolumn{2}{|c|}{ 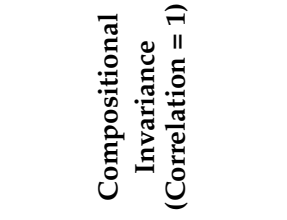 } & \multirow{2}{*}{ 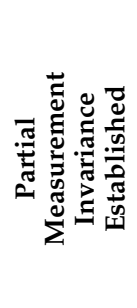 } & \multicolumn{3}{|c|}{ 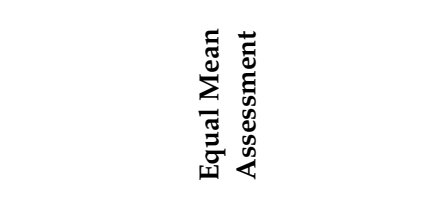 } & \multicolumn{3}{|c|}{ 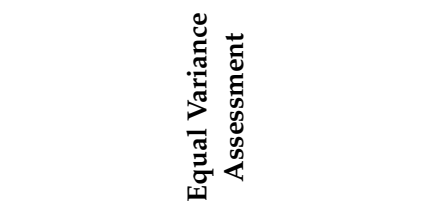 } & \multirow{2}{*}{ 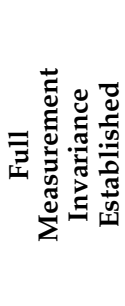 } \\
\hline & & $C=1$ & $\begin{array}{c}\text { Confidence } \\
\text { Interval }\end{array}$ & & Differ. & $\begin{array}{c}\text { Confidence } \\
\text { Interval }\end{array}$ & Equal & Differ. & $\begin{array}{c}\text { Confidence } \\
\text { Interval }\end{array}$ & Equal & \\
\hline Ethno. & Yes & 0.987 & $0.176-1.000$ & Yes & -0.134 & $\begin{array}{c}-0.274- \\
0.280\end{array}$ & Yes & -0.246 & $\begin{array}{c}-0.537- \\
0.539\end{array}$ & Yes & Yes \\
\hline O.Q. & Yes & 0.996 & $\begin{array}{c}-0.872- \\
1.000\end{array}$ & Yes & -0.617 & $\begin{array}{c}-0.267- \\
0.271\end{array}$ & No & -0.458 & $\begin{array}{c}-0.383- \\
0.385\end{array}$ & No & No \\
\hline B.I. & Yes & 0.987 & $\begin{array}{c}-0.982- \\
1.000\end{array}$ & Yes & 0.912 & $\begin{array}{c}-0.218- \\
0.277\end{array}$ & No & -0.035 & $\begin{array}{c}-0.307- \\
0.305\end{array}$ & Yes & No \\
\hline
\end{tabular}

Note: Ethno = Etnocentrism; E.Q.A. = EVOO Quality Attributes; B.I. = Behavioral Intention.

After completing the MICOM procedure and confirming the existence of invariance, the next step involved conducting MGA using the nonparametric methods of Henseler's MGA and permutation test. Henseler's MGA directly compares group-specific bootstrap estimates from each bootstrap sample. According to this method, a $p$-value of differences between path coefficients lower than 0.05 or higher than 0.95 indicates a $5 \%$ level of significant differences between specific path coefficients across groups [127]. On the other hand, the permutation test examines differences in the weights of the indicators used to measure each construct as well as the relationships among the constructs across the groups. Table 6 shows the results of both methods. The results confirm the importance of the results on the differences between the Spanish and Italian labels in the effects of ethnocentrism in 
the evaluation of the EVOO Quality Attributes and Behavioral Intention, which prevents rejection of $\mathrm{H} 3 \mathrm{a}$ and $\mathrm{H} 3 \mathrm{~b}$.

Table 6. Results of Multigroup Analysis.

\begin{tabular}{|c|c|c|c|c|c|c|c|}
\hline \multirow{2}{*}{ Relationships } & \multicolumn{2}{|c|}{ Path Coefficient } & \multicolumn{2}{|c|}{ Confidence Interval (95\%) } & \multirow{2}{*}{$\begin{array}{c}\text { Path } \\
\text { Coefficient } \\
\text { Difference }\end{array}$} & \multicolumn{2}{|c|}{$\begin{array}{c}p \text {-Value Difference } \\
\text { (One-Tailed) }\end{array}$} \\
\hline & Spanish & Italian & Spanish & Italian & & $\begin{array}{l}\text { Henseler's } \\
\text { MGA }\end{array}$ & $\begin{array}{c}\text { Permutation } \\
\text { Test }\end{array}$ \\
\hline Ethno. $\rightarrow$ O.Q. & 0.357 & -0.348 & $-0.534,0.452$ & $-0.473,0.291$ & 0.705 & 0.008 & 0.000 \\
\hline Ethno. $\rightarrow$ B.I. & 0.382 & -0.296 & $-0.542,0.475$ & $-0.371,0.490$ & 0.678 & 0.014 & 0.000 \\
\hline
\end{tabular}

Note: Ethno. = Etnocentrism; E.Q.A. = EVOO Quality Attributes; B.I. = Behavioral Intention.

\section{Discussion and Conclusions}

The main goal of this study was to determine the effect of $\mathrm{CE}$ on consumer behavioral intention and evaluation of EVOO according to the COO identified through its label. The results obtained allow us to affirm that ethnocentric consumers have significantly positive behavior regarding purchase intention and consumption of EVOO in their own country, which confirms the results obtained in previous studies (e.g., references $[5,25,31,53,72,95,100,101]$ ). However, the main contribution of this study is the determination of the effect of $\mathrm{CE}$ on the assessment of perceived product quality. This is the first study to establish this relationship in the olive oil market. The results show that the $\mathrm{COO}$ variable establishes significant differences in the general evaluation of the product and the taste between EVOO identified as domestic and foreign. This result supports those obtained by Harcar and Kaynak [30] and Basfirinci and Cilingir [11], who established that the effect of $\mathrm{COO}$ determines differences in the taste of soft drinks and chocolate, respectively. However, unlike these previous studies, our research found a direct and significant effect of CE on the assessment of product quality. These results establish the need to specifically study the characteristics of the analyzed food product, since, although, there are no significant differences found in taste, it is possible that other fundamental variables that determine product quality may show significant differences, according to the COO.

On the other hand, as the literature indicates, CE affects, in a significantly different way, the valuation and behavioral intention associated with foreign products. The results in our study allow us to affirm that there is a significantly inverse relationship between consumers who are biased toward purchasing domestic food products and the intention to purchase products from other countries, thus confirming the results of previous research $[13,22,31,95]$. In the case of the evaluation of the quality attributes of the EVOO, although there is a significantly negative relationship, the explained variance is very small, which suggests that another series of variables not included in this study affects the assessment of the quality of foreign products. The results obtained concerning the levels of ethnocentrism according to age are similar to previous studies (e.g., references $[25,72,86])$, enabling confirmation that young people do not show high levels of ethnocentrism; instead, they mainly display a protective attitude toward food products and the economy, in general, of their country. However, the levels shown are sufficient to determine a significantly negative relationship between the perception of the EVOO from Italy and behavioral intention. Therefore, it is possible to affirm that ethnocentrism, even at low levels, has a determining effect not only on the better evaluation of national products but also on the rejection of foreign products. This has important implications at a theoretical level, since it is not only important to differentiate between high and low levels of ethnocentrism in the consumer but also to determine to what extent $\mathrm{CE}$ directly affects consumer behavior and perception.

This research advances understanding of the effects of $\mathrm{CE}$ and the $\mathrm{COO}$ cue on consumers' product evaluations and contributes to the literature on the food industry. As Basfirinci and Cilingir [11] state, in the food literature, most studies focus on external aspects, such as $\mathrm{COO}$, without including important intrinsic cues; thus, further experi- 
mental studies for food products are required. Given that the evaluation of the quality of a product depends on direct experience and given the complexity of a product such as EVOO, this study developed an experimental design using real product experience, in which multiple variables related to the quality of the product were analyzed, not just the taste. It has been possible to demonstrate that ethnocentrism significantly affects the evaluation of the quality attributes of EVOO. When the COO was considered in isolation, the results only showed significant differences for the variables of general opinion and taste, but when analyzing the structural relationship between CE and the assessment of EVOO Quality Attributes, including different related variables, it was possible to identify a positive relationship with domestic products and a negative relationship with foreign products. On the other hand, the results allow confirmation of the conclusions of previous studies regarding the low levels of ethnocentrism. However, we have been able to show that, even when the consumer has low levels of $\mathrm{CE}$, they still maintain their preference for national products over foreign ones, which has important implications for companies.

Our empirical findings are useful for guiding managerial implications in olive oil producers and retailers. Currently, companies must develop commercial strategies to satisfy the needs of local and global consumers, trying to improve their global competitiveness but without ceasing to pay attention to local markets [72]. However, the consumer purchasing decision process is more complex, as it is influenced by diverse information that affects consumer behavior and determines their preferences for national or international brands. Globalization has caused the origin of products to become a fundamental element in product differentiation, especially with food products, given the close cultural ties [7].

Understanding consumer preferences and behaviors regarding local products is a critical element that can help managers exploit all business opportunities, which will enhance local food industries and support local business. The literature has identified several reasons for buying domestic foods (see [108] for a review), among which the following stand out: health-related issues [11], which has caused an increase in demand for high-quality, functional, or sustainable products; paying special attention to elements related to "emotional value" [7]; and an opposition to globalization in food production, which has focused on social aspects related to sustainability [6]. This behavior relates to support of local products and "can constitute a direct response to the needs of the ethnocentric consumer" [130] (p. 149). Thus, since understanding EC levels in a market can determine the success or failure of a particular product, the appropriate use of $\mathrm{COO}$ identifiers can provide competitive advantages based on the product [131].

The use of $\mathrm{COO}$ identification elements is, thus a, fundamental indicator in the consumer decision-making process. In the case of EVOO, with strong roots in culture and characterized by its beneficial properties for health, product origin allows communication of information on the characteristics of the product and signals the overall quality of a product $[61,62,132]$. Therefore, it is important that EVOO producers begin to pay attention to promotional and communication activities, developing strategies based on the generation of added-value brands for consumers. Some producers are starting to use private-label foods, such as apples, melons, or watermelons. Creating a brand can be difficult and expensive for small olive oil farms; however, joint brands that protect products from the same region ("foods from...") or identify different agents of the distribution channel through tradition and the authenticity would be taking important actions to achieve this objective.

The effectiveness of this policy will depend on the value that consumers place in these brands. In some cases, the consumer does not have a clear understanding of the characteristics of the quality labels [133]. Therefore, communication and promotional campaigns aimed at informing consumers about local quality products and brands are also necessary. From the consumer perspective, the CE concept can help olive oil retailers and farmers ensure the sustainability of their territory [134], utilizing sentiments of consumer ethnocentrism through labeling programs to promote domestic products. Furthermore, it is possible to develop market segmentation strategies based on the ethnocentric attitudes of the different market groups. CE helps predict national and international consumers' 
responses to marketing activities for food products. In the same way, consumer "education" is also important, through the development of campaigns explaining how consuming local food supports local businesses [5]. Finally, in the specific case of EVOO, its organoleptic characteristics (taste, color) constitute an important element that must be considered for differentiation [7]. That consumers know the characteristics of EVOO and can differentiate it from other types of oils is an important challenge that involves improving consumer knowledge so that they can appreciate it better.

This study has some limitations that offer the possibility of proposing future studies. Although the results show frequent consumption of EVOO by the sample, information on the level of knowledge of the participants regarding the product has not been included. Previous studies have concluded that CE is associated with consumer knowledge of the product [103] and that greater ethnocentric behavior reduces consumer knowledge of product attributes. Ricci et al. [53] found that the purchase frequency of Italian products among customers in Germany is not so associated with ethnocentrism but with personal knowledge about the products. Therefore, as a future study, the inclusion of information regarding the degree of knowledge about the EVOO is proposed. Previous studies have analyzed the differences between groups with low and high ethnocentrism according to the mean or the split means (e.g., references $[31,56,80,86,111])$. Therefore, it would be interesting to apply the model according to the level of ethnocentrism or to include a group of older people, usually considered as a group with a greater level of ethnocentrism.

A second limitation of this study is that we carried out the study with participants from the same country. Given that ethnocentricity and the factors influencing it vary from country to country [22], as a future line of inquiry, it would be interesting to replicate the study with Italian consumers, allowing the results to be confirmed in a cross-cultural context. Furthermore, the inclusion of a third country in the experiment; the inclusion of more variables that have been shown to affect consumer choice, such as price $[52,86]$; or conducting the study in a regional setting are other future study alternatives that emanate from the current work. Finally, although studies on CE and COO have focused on consumer choices between domestic and imported products, recent studies have applied a regional or local level of analysis [6,134,135]. Bryła [134] stated that regional ethnocentric consumers were characterized by a significantly more favorable attitude toward regional food products, compared to the rest of the sample. Fernández-Ferrín et al. [6], based on a sample of Basque Country consumers, observed that consumers' ethnocentric tendencies had a significant influence on their intention to buy products from the region. Therefore, given that EVOO has characteristics closely related to the region of production, the use of labels at a regional or local level is proposed as a future area of study.

Author Contributions: This paper is the result of teamwork. The study was conceived of and designed by J.J.B.-R. and S.G.-B. P.J.-E. and I.R.P.-J. contributed significantly to the data collection, elaboration, and analysis. The authors contributed equally to writing the paper and integrating and organizing the results. All authors have read and agreed to the published version of the manuscript.

Funding: This research received no external funding.

Institutional Review Board Statement: Not applicable.

Informed Consent Statement: Not applicable.

Data Availability Statement: Not applicable.

Acknowledgments: We would like to express our sincere gratitude to the editor and anonymous referees for their insightful and constructive comments to improve the quality of the paper.

Conflicts of Interest: The authors declare no conflict of interest. 


\section{Appendix A}

\begin{tabular}{|c|c|}
\hline & Item \\
\hline Ethno1 & Buying products made abroad is anti-Spanish \\
\hline Ethno2 & It is not good to buy foreign products, because it leaves the Spanish without work \\
\hline Ethno3 & A true Spaniard should always buy products made in Spain \\
\hline Ethno4 & $\begin{array}{l}\text { We should buy products made in Spain instead of allowing other countries to get } \\
\text { rich at our expense }\end{array}$ \\
\hline Ethno5 & It is best to always buy Spanish products \\
\hline Ethno6 & $\begin{array}{l}\text { Spaniards should not buy foreign products that harm Spanish companies and cause } \\
\text { unemployment }\end{array}$ \\
\hline Ethno7 & Foreigners should not be allowed to put their products on our markets \\
\hline Ethno8 & Foreign products should be heavily taxed to reduce their entry into Spain \\
\hline Ethno9 & $\begin{array}{c}\text { Spanish consumers who buy products made in other countries are responsible for } \\
\text { making their compatriots unemployed }\end{array}$ \\
\hline
\end{tabular}

\section{References}

1. Nelson, C.J. Sustainability of Agriculture. J. Crop. Improv. 2007, 19, 1-24. [CrossRef]

2. Strange, T.; Bayley, A. Sustainable Development. Linking Economy, Society, Environment; OECD Insights, OECD Publishing: Paris, France, 2008.

3. Menozzi, D. Extra-Virgin Olive Oil Production Sustainability in Northern Italy: A Preliminary Study. Br. Food J. 2014, 116, 1942-1959. [CrossRef]

4. Aprile, M.C.; Caputo, V.; Nayga, R.M., Jr. Consumers' Valuation of Food Quality Labels: The Case of the European Geographic Indication and Organic Farming Labels: Consumers' Valuation of Food Quality Labels. Int. J. Consum. Stud. 2012, 36, 158-165. [CrossRef]

5. Bianchi, C.; Mortimer, G. Drivers of Local Food Consumption: A Comparative Study. Br. Food J. 2015, 117, 2282-2299. [CrossRef]

6. Fernández-Ferrín, P.; Calvo-Turrientes, A.; Bande, B.; Artaraz-Miñón, M.; Galán-Ladero, M.M. The Valuation and Purchase of Food Products That Combine Local, Regional and Traditional Features: The Influence of Consumer Ethnocentrism. Food Qual. Prefer. 2018, 64, 138-147. [CrossRef]

7. Polenzani, B.; Riganelli, C.; Marchini, A. Sustainability Perception of Local Extra Virgin Olive Oil and Consumers' Attitude: A New Italian Perspective. Sustainability 2020, 12, 920. [CrossRef]

8. de Jaén, C.R. Informe Anual de Coyuntura Del Sector Oleícola; Caja Rural de Jaén: Jaen, Spain, 2020.

9. Menapace, L.; Colson, G.; Grebitus, C.; Facendola, M. Consumers' Preferences for Geographical Origin Labels: Evidence from the Canadian Olive Oil Market. Eur. Rev. Agric. Econ. 2011, 38, 193-212. [CrossRef]

10. Dmitrovic, T.; Vida, I.; Reardon, J. Purchase Behavior in Favor of Domestic Products in the West Balkans. Int. Bus. Rev. 2009, 18, 523-535. [CrossRef]

11. Basfirinci, C.; Cilingir, Z. Does Country of Origin Matter for Chocolate? Ethnocentrism, Involvement, and Perceived Risk for Turkish University Students. J. Food Prod. Mark. 2020, 26, 144-184. [CrossRef]

12. Dursun, I.; Kabadayi, E.T.; Ceylan, K.E.; Koksal, C.G. Russian Consumers' Responses to Turkish Products: Exploring the Roles of Country Image, Consumer Ethnocentrism, and Animosity. Bus. Econ. Res. J. 2019, 10, 499-516. [CrossRef]

13. Kilders, V.; Caputo, V.; Liverpool-Tasie, L.S.O. Consumer Ethnocentric Behavior and Food Choices in Developing Countries: The Case of Nigeria. Food Policy 2021, 99, 101973. [CrossRef]

14. Bilkey, W.J.; Nes, E. Country-of-Origin Effects on Product Evaluations. J. Int. Bus. Stud. 1982, 13, 89-100. [CrossRef]

15. Papadopoulos, N.; Heslop, L.A. Country Equity and Product-Country Images: State-of-the-Art in Research and Implications. In Handbook of Research in International Marketing; Edward Elgar Publishing: Cheltenham, UK, 2003. [CrossRef]

16. Chambers, S.; Lobb, A.; Butler, L.; Harvey, K.; Traill, W.B. Local, National and Imported Foods: A Qualitative Study. Appetite 2007, 49, 208-213. [CrossRef]

17. Verlegh, P.W.J.; Steenkamp, J.-B.E.M. A Review and Meta-Analysis of Country-of-Origin Research. J. Econ. Psychol. 1999, 20, 521-546. [CrossRef]

18. Insch, A.; Jackson, E. Consumer Understanding and Use of Country-of-Origin in Food Choice. Br. Food J. 2014, 116, 62-79. [CrossRef]

19. Resano, H.; Sanjuán, A.I.; Albisu, L.M. Consumers' Response to the EU Quality Policy Allowing for Heterogeneous Preferences. Food Policy 2012, 37, 355-365. [CrossRef]

20. Van Ittersum, K.; Candel, M.J.J.M.; Meulenberg, M.T.G. The Influence of the Image of a Product's Region of Origin on Product Evaluation. J. Bus. Res. 2003, 56, 215-226. [CrossRef]

21. Lusk, J.L.; Brown, J.; Mark, T.; Proseku, I.; Thompson, R.; Welsh, J. Consumer Behavior, Public Policy, and Country-of-Origin Labeling. Rev. Agric. Econ. 2006, 28, 284-292. [CrossRef]

22. Balabanis, G.; Diamantopoulos, A. Domestic Country Bias, Country-of-Origin Effects, and Consumer Ethnocentrism: A Multidimensional Unfolding Approach. J. Acad. Mark. Sci. 2004, 32, 80-95. [CrossRef] 
23. Cilingir, Z.; Basfirinci, C. The Impact of Consumer Ethnocentrism, Product Involvement, and Product Knowledge on Country of Origin Effects: An Empirical Analysis on Turkish Consumers' Product Evaluation. J. Int. Consum. Mark. 2014, 26, 284-310. [CrossRef]

24. Herche, J. A Note on the Predictive Validity of the CETSCALE. J. Acad. Mark. Sci. 1992, 20, 261-264. [CrossRef]

25. Orth, U.R.; Firbasová, Z. The Role of Consumer Ethnocentrism in Food Product Evaluation: Role Of Consumer Ethnocentrism In Food Product Evaluation. Agribusiness 2003, 19, 137-153. [CrossRef]

26. Barlagne, C.; Bazoche, P.; Thomas, A.; Ozier-Lafontaine, H.; Causeret, F.; Blazy, J.-M. Promoting Local Foods in Small Island States: The Role of Information Policies. Food Policy 2015, 57, 62-72. [CrossRef]

27. Guo, G.; Zhou, X. Consumer Ethnocentrism on Product Judgment and Willingness to Buy: A Meta-Analysis. Soc. Behav. Pers. Int. J. 2017, 45, 163-176. [CrossRef]

28. Iacob, A.I. Country-Of-Origin Effect and Consumer Brand Perception. Ph.D. Thesis, Aalborg University, Aalborg, Denmark, 2014.

29. Caputo, V.; Scarpa, R.; Nayga, R.M., Jr. Cue versus Independent Food Attributes: The Effect of Adding Attributes in Choice Experiments. Eur. Rev. Agric. Econ. 2017, 44, 211-230. [CrossRef]

30. Harcar, T.; Kaynak, E. The Impact of Country-of-Origin and Ethnocentrism: An Experimental Study of Consumer Taste Preferences for Soft Drinks at Cross-Cultural Level. J. Euromarketing 2015, 24, 120-131. [CrossRef]

31. Chryssochoidis, G.; Krystallis, A.; Perreas, P. Ethnocentric Beliefs and Country-of-origin (COO) Effect: Impact of Country, Product and Product Attributes on Greek Consumers' Evaluation of Food Products. Eur. J. Mark. 2007, 41, 1518-1544. [CrossRef]

32. Evanschitzky, H.; Wangenheim, F.; Woisetschläger, D.; Blut, M. Consumer Ethnocentrism in the German Market. Int. Mark. Rev. 2008, 25, 7-32. [CrossRef]

33. Nagashima, A. A Comparison of Japanese and U.S. Attitudes toward Foreign Products. J. Mark. 1970, 34, 68-74. [CrossRef]

34. Schooler, R.D. Product Bias in the Central American Common Market. J. Mark. Res. 1965, 2, 394-397. [CrossRef]

35. Papadopoulos, N.; Heslop, L.A. Product-Country Images: Impact and Role in International Marketing; Routledge: New York, NY, USA, 2014; ISBN 978-1-317-95319-7.

36. Roth, K.P.; Diamantopoulos, A. Advancing the Country Image Construct. J. Bus. Res. 2009, 62, 726-740. [CrossRef]

37. Dinnie, K. Country-of-Origin 1965-2004: A Literature Review. J. Cust. Behav. 2004, 3, 165-213. [CrossRef]

38. Liefeld, J.P. ReExperiments on country-of-origin effects: Review and meta-analysis of effect sizeview and Meta-Analysis of Effect Size. In Product Country Images: Impact and Role in International Marketing; International Business Press: New York, NY, USA, 1993; pp. 117-156. ISBN 1560242361.

39. Usunier, J.-C. Relevance in Business Research: The Case of Country-of-Origin Research in Marketing. Eur. Manag. Rev. 2006, 3, 60-73. [CrossRef]

40. Chamorro-Mera, A.; Román-Suero, B.; García-Galán, M.D.M. The Structure of Preferences of Olive Oil Importers: The Country of Origin Effect. J. Food Prod. Mark. 2020, 26, 457-469. [CrossRef]

41. Tempesta, T.; Vecchiato, D. Vecchiato Analysis of the Factors That Influence Olive Oil Demand in the Veneto Region (Italy). Agriculture 2019, 9, 154. [CrossRef]

42. Verlegh, P.W.J.; Steenkamp, J.-B.E.M.; Meulenberg, M.T.G. Country-of-Origin Effects in Consumer Processing of Advertising Claims. Int. J. Res. Mark. 2005, 22, 127-139. [CrossRef]

43. Pieniak, Z.; Verbeke, W.; Vanhonacker, F.; Guerrero, L.; Hersleth, M. Association between Traditional Food Consumption and Motives for Food Choice in Six European Countries. Appetite 2009, 53, 101-108. [CrossRef] [PubMed]

44. Van Ittersum, K.; Meulenberg, M.T.G.; Trijp, H.C.M.V.; Candel, M.J.J.M. Consumers' Appreciation of Regional Certification Labels: A Pan-European Study. J. Agric. Econ. 2007, 58, 1-23. [CrossRef]

45. Veale, R.; Quester, P. Do Consumer Expectations Match Experience? Predicting the Influence of Price and Country of Origin on Perceptions of Product Quality. Int. Bus. Rev. 2009, 18, 134-144. [CrossRef]

46. Bonnet, C.; Simioni, M. Assessing Consumer Response to Protected Designation of Origin Labelling: A Mixed Multinomial Logit Approach. Eur. Rev. Agric. Econ. 2001, 28, 433-449. [CrossRef]

47. Huddleston, P.; Good, L.K.; Stoel, L. Consumer Ethnocentrism, Product Necessity and Polish Consumers' Perceptions of Quality. Int. J. Retail Distrib. Manag. 2001, 29, 236-246. [CrossRef]

48. Fandos, C.; Flavián, C. Intrinsic and Extrinsic Quality Attributes, Loyalty and Buying Intention: An Analysis for a PDO Product. Br. Food J. 2006, 108, 646-662. [CrossRef]

49. Font i Furnols, M.; Realini, C.; Montossi, F.; Sañudo, C.; Campo, M.M.; Oliver, M.A.; Nute, G.R.; Guerrero, L. Consumer's Purchasing Intention for Lamb Meat Affected by Country of Origin, Feeding System and Meat Price: A Conjoint Study in Spain, France and United Kingdom. Food Qual. Prefer. 2011, 22, 443-451. [CrossRef]

50. Ahmed, Z.U.; Johnson, J.P.; Yang, X.; Kheng Fatt, C.; Sack Teng, H.; Chee Boon, L. Does Country of Origin Matter for Lowinvolvement Products? Int. Mark. Rev. 2004, 21, 102-120. [CrossRef]

51. Grunert, K.G.; Aachmann, K. Consumer Reactions to the Use of EU Quality Labels on Food Products: A Review of the Literature. Food Control 2016, 59, 178-187. [CrossRef]

52. Erraach, Y.; Sayadi, S.; Gomez, A.C.; Parra-Lopez, C. Consumer-Stated Preferences towards Protected Designation of Origin (PDO) Labels in a Traditional Olive-Oil-Producing Country: The Case of Spain. New Medit 2014, 13, 11-19.

53. Ricci, E.C.; Stranieri, S.; Casetta, C.; Soregarol, C. Consumer Preferences for Made in Italy Food Products: The Role of Ethnocentrism and Product Knowledge. AIMS Agric. Food 2019, 4, 88-110. [CrossRef] 
54. Luomala, H.T. Exploring the Role of Food Origin as a Source of Meanings for Consumers and as a Determinant of Consumers' Actual Food Choices. J. Bus. Res. 2007, 60, 122-129. [CrossRef]

55. Moser, R.; Raffaelli, R.; Thilmany, D.D. Consumer Preferences for Fruit and Vegetables with Credence-Based Attributes: A Review. Int. Food Agribus. Manag. Rev. 2011, 14, 121-142. [CrossRef]

56. Van Loo, E.J.; Grebitus, C.; Roosen, J. Explaining Attention and Choice for Origin Labeled Cheese by Means of Consumer Ethnocentrism. Food Qual. Prefer. 2019, 78, 103716. [CrossRef]

57. Sousa, A.; Nobre, H.; Farhangmehr, M. Exploring the Effects of Ethnocentrism and Country Familiarity in Consumer Preference and Brand Recognition. Int. J. Bus. Glob. 2018, 20, 139-151. [CrossRef]

58. Panico, T.; Giudice, T.D.; Caracciolo, F. Quality Dimensions and Consumer Preferences: A Choice Experiment in the Italian Extra-Virgin Olive Oil Market. Agric. Econ. Rev. 2014, 15, 13. [CrossRef]

59. Ballco, P.; Gracia, A. Do Market Prices Correspond with Consumer Demands? Combining Market Valuation and Consumer Utility for Extra Virgin Olive Oil Quality Attributes in a Traditional Producing Country. J. Retail. Consum. Serv. 2020, 53, 101999. [CrossRef]

60. Caporale, G.; Policastro, S.; Carlucci, A.; Monteleone, E. Consumer Expectations for Sensory Properties in Virgin Olive Oils. Food Qual. Prefer. 2006, 17, 116-125. [CrossRef]

61. Delgado, C.; Guinard, J.-X. How Do Consumer Hedonic Ratings for Extra Virgin Olive Oil Relate to Quality Ratings by Experts and Descriptive Analysis Ratings? Food Qual. Prefer. 2011, 22, 213-225. [CrossRef]

62. Krystallis, A.; Ness, M. Consumer Preferences for Quality Foods from a South European Perspective: A Conjoint Analysis Implementation on Greek Olive Oil. Int. Food Agribus. Manag. Rev. 2005, 8, 62-91. [CrossRef]

63. Chan-Halbrendt, C.; Zhllima, E.; Sisior, G.; Imami, D.; Leonetti, L. Consumer Preferences for Olive Oil in Tirana, Albania. Int. Food Agribus. Manag. Rev. 2010, 13. [CrossRef]

64. Mtimet, N.; Zaibet, L.; Zairi, C.; Hzami, H. Marketing Olive Oil Products in the Tunisian Local Market: The Importance of Quality Attributes and Consumers' Behavior. J. Int. Food Agribus. Mark. 2013, 25, 134-145. [CrossRef]

65. Romo-Muñoz, R.A.; Cabas-Monje, J.H.; Garrido-Henrríquez, H.M.; Gil, J.M. Heterogeneity and Nonlinearity in Consumers' Preferences: An Application to the Olive Oil Shopping Behavior in Chile. PLoS ONE 2017, 12, e0184585. [CrossRef]

66. Van der Lans, I.A.; Van Ittersum, K.; De Cicco, A.; Loseby, M. The Role of the Region of Origin and EU Certificates of Origin in Consumer Evaluation of Food Products. Eur. Rev. Agric. Econ. 2001, 28, 451-477. [CrossRef]

67. Boncinelli, F.; Contini, C.; Romano, C.; Scozzafava, G.; Casini, L. Territory, Environment, and Healthiness in Traditional Food Choices: Insights into Consumer Heterogeneity. Int. Food Agribus. Manag. Rev. 2017, 20, 143-157. [CrossRef]

68. Giannoccaro, G.; Carlucci, D.; Sardaro, R.; Roselli, L.; De Gennaro, B.C. Assessing Consumer Preferences for Organic vs Eco-Labelled Olive Oils. Org. Agric. 2019, 9, 483-494. [CrossRef]

69. Bimbo, F.; Roselli, L.; Carlucci, D.; de Gennaro, B.C. Consumer Misuse of Country-of-Origin Label: Insights from the Italian Extra-Virgin Olive Oil Market. Nutrients 2020, 12, 2150. [CrossRef]

70. Ward, R.W.; Briz, J.; de Felipe, I. Competing Supplies of Olive Oil in the German Market: An Application of Multinomial Logit Models. Agribusiness 2003, 19, 393-406. [CrossRef]

71. Cavallo, C.; Piqueras-Fiszman, B. Visual Elements of Packaging Shaping Healthiness Evaluations of Consumers: The Case of Olive Oil. J. Sens. Stud. 2017, 32, e12246. [CrossRef]

72. Al Ganideh, S.F.; Good, L.K. Nothing Tastes as Local: Jordanians' Perceptions of Buying Domestic Olive Oil. J. Food Prod. Mark. 2016, 22, 168-190. [CrossRef]

73. Espejel, J.; Fandos, C.; Flavián, C. The Influence of Consumer Degree of Knowledge on Consumer Behavior: The Case of Spanish Olive Oil. J. Food Prod. Mark. 2008, 15, 15-37. [CrossRef]

74. Yangui, A.; Costa-Font, M.; Gil, J.M. Revealing Additional Preference Heterogeneity with an Extended Random Parameter Logit Model: The Case of Extra Virgin Olive Oil. Span. J. Agric. Res. 2014, 12, 553. [CrossRef]

75. Yangui, A.; Costa-Font, M.; Gil, J.M. The Effect of Personality Traits on Consumers' Preferences for Extra Virgin Olive Oil. Food Qual. Prefer. 2016, 51, 27-38. [CrossRef]

76. Bernabéu, R.; Díaz, M. Preference for Olive Oil Consumption in the Spanish Local Market. Span. J. Agric. Res. 2016, 14, e0108. [CrossRef]

77. García-Gallego, J.M.; Chamorro Mera, A. COO vs ROO: Importance of the Origin in Customer Preferences towards Financial Entities. Int. Mark. Rev. 2017, 34, 206-223. [CrossRef]

78. Sumner, W.G. A Study of the Sociological Importance of Usages, Manners, Customs, Mores, and Morals; Ginn and Company: Boston, MA, USA, 1906.

79. Lynn, R. Sociobiology of Nationalism. New Soc. 1976, 37, 11-14.

80. Shimp, T.A.; Sharma, S. Consumer Ethnocentrism: Construction and Validation of the CETSCALE. J. Mark. Res. 1987, 24, 280-289. [CrossRef]

81. Sharma, S.; Shimp, T.A.; Shin, J. Consumer Ethnocentrism: A Test of Antecedents and Moderators. J. Acad. Mark. Sci. 1994, 23, 26-37. [CrossRef]

82. Tirelli, C.; Pilar Martínez-Ruiz, M.; Gómez-Ladrón-De-Guevara, R. Assessing the Impact of Ethnocentrism in the Food Buying Decisions of International University Students. J. Food Prod. Mark. 2016, 22, 279-303. [CrossRef] 
83. Schnettler, B.; Miranda, H.; Lobos, G.; Sepúlveda, J.; Denegri, M. A Study of the Relationship between Degree of Ethnocentrism and Typologies of Food Purchase in Supermarkets in Central-Southern Chile. Appetite 2011, 56, 704-712. [CrossRef]

84. Shankarmahesh, M.N. Consumer Ethnocentrism: An Integrative Review of Its Antecedents and Consequences. Int. Mark. Rev. 2006, 23, 146-172. [CrossRef]

85. Luque-Martínez, T.; Ibáñez-Zapata, J.; del Barrio-García, S. Consumer Ethnocentrism Measurement-An Assessment of the Reliability and Validity of the CETSCALE in Spain. Eur. J. Mark. 2000, 34, 1353-1374. [CrossRef]

86. Bernabéu, R.; Oliveira, F.; Rabadan, A.; Diaz, M. Influence of Ethnocentrism on Consumer Preference Patterns: The Case of Olive Oil in Portugal. New Medit Mediterr. J. Econ. Agric. Environ. Rev. Méditerranéenne D'Economie Agric. Environ. 2020, 19, 55-68. [CrossRef]

87. Myers, M.B. Ethnocentrism: A Literature Overview and Directions for Future Research. In Proceedings of the 1995 Academy of Marketing Science (AMS) Annual Conference, Orlando, FL, USA, 17-20 May 1995; Springer: Berlin/Heidelberg, Germany, 2015; pp. 202-207.

88. Shimp, T.A.; Samiee, S.; Madden, T.J. Countries and Their Products: A Cognitive Structure Perspective. J. Acad. Mark. Sci. 1993, 21, 323-330. [CrossRef]

89. Yagci, M.I. Evaluating the Effects of Country-of-Origin and Consumer Ethnocentrism. J. Int. Consum. Mark. 2001, 13, 63-85. [CrossRef]

90. Philp, K.; Brown, L. Does Consumer Ethnocentrism Impact on Australian Food Buying Behaviour. J. New Bus. Ideas Trends 2003, $1,21-43$.

91. Bernabéu, R.; Prieto, A.; Díaz, M. Preference Patterns for Wine Consumption in Spain Depending on the Degree of Consumer Ethnocentrism. Food Qual. Prefer. 2013, 28, 77-84. [CrossRef]

92. Camarena, D.M.; Sanjuán, A.I.; Philippidis, G. Influence of Ethnocentrism and Neo-Phobia on Ethnic Food Consumption in Spain. Appetite 2011, 57, 121-130. [CrossRef] [PubMed]

93. Romo, R.; Gil, J.M. Ethnic Identity and Dietary Habits among Hispanic Immigrants in Spain. Br. Food J. 2012, 114, 206-223. [CrossRef]

94. Mollá-Bauzá, M.B.; Poveda, Á.M.; Martínez, L.M.-C. Aceptación de productos agrarios propios en los mercados locales: El aceite de oliva virgen extra en la Comunidad Valenciana. Rev. Esp. Estud. Agrosoc. Pesq. 2010, 226, 207-224. [CrossRef]

95. Lewis, K.E.; Grebitus, C. Why U.S. Consumers Support Country of Origin Labeling: Examining the Impact of Ethnocentrism and Food Safety. J. Int. Food Agribus. Mark. 2016, 28, 254-270. [CrossRef]

96. Schnettler, B.; Sánchez, M.; Miranda, H.; Orellana, L.; Mora, M.; Lobos, G.; Hueche, C. "Country of Origin" Effect and Ethnocentrism in Food Purchase in Southern Chile. Rev. Fac. Cienc. Agrar. 2017, 49, 243-267.

97. Klein, J.G.; Ettenson, R.; Morris, M.D. The Animosity Model of Foreign Product Purchase: An Empirical Test in the People's Republic of China. J. Mark. 1998, 62, 89-100. [CrossRef]

98. Moon, B.J.; Jain, S.C. Consumer Processing of Foreign Advertisements: Roles of Country-of-Origin Perceptions, Consumer Ethnocentrism, and Country Attitude. Int. Bus. Rev. 2002, 11, 117-138. [CrossRef]

99. Pharr, J.M. Synthesizing Country-of-Origin Research from the Last Decade: Is the Concept Still Salient in an Era of Global Brands? J. Mark. Theory Pract. 2005, 13, 34-45. [CrossRef]

100. Kavak, B.; Gumusluoglu, L. Segmenting Food Markets-The Role of Ethnocentrism and Lifestyle in Understanding Purchasing Intentions. Int. J. Mark. Res. 2007, 49, 71-94. [CrossRef]

101. Qing, P.; Lobo, A.; Chongguang, L. The Impact of Lifestyle and Ethnocentrism on Consumers' Purchase Intentions of Fresh Fruit in China. J. Consum. Mark. 2012, 29, 43-51. [CrossRef]

102. Urbonavičius, S.; Dikčius, V.; Petrauskas, A. Impact of Ethnocentrism on Buyer's Choice of Organic Food Products. In Proceedings of the The 6th International Scientific Conference "Business and Management 2010"; Selected papers; Vilnius Gediminas Technical University Publishing House Technika: Vilnius, Lithuania, 2010; pp. 511-517.

103. Seitz, C.C.; Roosen, J. Does Consumer Ethnocentrism Influence Product Knowledge? Food Qual. Prefer. 2015, 43, 113-121. [CrossRef]

104. Ehmke, M.D.; Lusk, J.L.; Tyner, W. Measuring the Relative Importance of Preferences for Country of Origin in China, France, Niger, and the United States. Agric. Econ. 2008, 38, 277-285. [CrossRef]

105. Olson, J.C. What Is an Esthetic Response? In SV-Symbolic Consumer Behavior; Holbrook: New York, NY, USA, 1981; Volume SV-04, pp. 71-74.

106. Steenkamp, J.-B.E.M.; Van Trijp, H.C.M. Quality Guidance: A Consumer-Based Approach to Food Quality Improvement Using Partial Least Squares. Eur. Rev. Agric. Econ. 1996, 23, 195-215. [CrossRef]

107. Steenkamp, J.-B.E.M. Conceptual Model of the Quality Perception Process. J. Bus. Res. 1990, 21, 309-333. [CrossRef]

108. Rakic, M.; Rakic, B.; Stanojevic, L. Encouraging Consumer Ethnocentrism in the Function of Domestic Foodstuffs Consumption. Econ. Agric. 2019, 66, 341-355. [CrossRef]

109. Reboredo-Rodríguez, P.; González-Barreiro, C.; Cancho-Grande, B.; Fregapane, G.; Salvador, M.D.; Simal-Gándara, J. Characterisation of Extra Virgin Olive Oils from Galician Autochthonous Varieties and Their Co-Crushings with Arbequina and Picual Cv. Food Chem. 2015, 176, 493-503. [CrossRef]

110. Diamantopoulos, A.; Schlegelmilch, B.; Palihawadana, D. The Relationship between Country-of-origin Image and Brand Image as Drivers of Purchase Intentions: A Test of Alternative Perspectives. Int. Mark. Rev. 2011, 28, 508-524. [CrossRef]

111. Good, L.K.; Huddleston, P. Ethnocentrism of Polish and Russian Consumers: Are Feelings and Intentions Related. Int. Mark. Rev. 1995, 12, 35-48. [CrossRef] 
112. Ampuero, O.; Vila, N. Consumer Perceptions of Product Packaging. J. Consum. Mark. 2006, 23, 100-112. [CrossRef]

113. Delgado, C.; Gómez-Rico, A.; Guinard, J.-X. Evaluating Bottles and Labels versus Tasting the Oils Blind: Effects of Packaging and Labeling on Consumer Preferences, Purchase Intentions and Expectations for Extra Virgin Olive Oil. Food Res. Int. 2013, 54, 2112-2121. [CrossRef]

114. Cicia, G.; Del Giudice, T.; Scarpa, R. Consumers' Perception of Quality in Organic Food: A Random Utility Model under Preference Heterogeneity and Choice Correlation from Rank-orderings. Br. Food J. 2002, 104, 200-213. [CrossRef]

115. Hair, J.F.; Risher, J.J.; Sarstedt, M.; Ringle, C.M. When to Use and How to Report the Results of PLS-SEM. Eur. Bus. Rev. 2019, 31, 2-24. [CrossRef]

116. Sharma, P.N.; Shmueli, G.; Sarstedt, M.; Danks, N.; Ray, S. Prediction-Oriented Model Selection in Partial Least Squares Path Modeling. Decis. Sci. 2018. [CrossRef]

117. Ringle, C.M.; Wende, S.; Becker, J.-M. SmartPLS 3: Bönningstedt, Germany. 2015. Available online: http:/ /www.smartpls.com (accessed on 23 April 2021).

118. Dekhili, S.; d'Hauteville, F. Effect of the Region of Origin on the Perceived Quality of Olive Oil: An Experimental Approach Using a Control Group. Food Qual. Prefer. 2009, 20, 525-532. [CrossRef]

119. Nielsen, J.A.; Spence, M.T. A Test of the Stability of the Cetscale, A Measure of Consumers' Ethnocentric Tendencies. J. Mark. Theory Pract. 1997, 5, 68-76. [CrossRef]

120. Klein, J.G.; Ettenson, R.; Krishnan, B.C. Extending the Construct of Consumer Ethnocentrism: When Foreign Products Are Preferred. Int. Mark. Rev. 2006, 23, 304-321. [CrossRef]

121. Lee, W.-N.; Hong, J.-Y.; Lee, S.-J. Communicating with American Consumers in the Post 9/11 Climate: An Empirical Investigation of Consumer Ethnocentrism in the United States. Int. J. Advert. 2003, 22, 487-510. [CrossRef]

122. Roldán, J.L.; Sánchez-Franco, M.J. Variance-Based Structural Equation Modeling: Guidelines for Using Partial Least Squares in Information Systems Research. In Research Methodologies, Innovations and Philosophies in Software Systems Engineering and Information Systems; IGI Global: Hershey, PA, USA, 2012; pp. 193-221. [CrossRef]

123. Nunnally, J.C.; Bernstein, I.H. Psychometric Theory, 3rd ed.; McGraw-Hill: New York, NY, USA, 1994.

124. Hair, J.F.; Ringle, C.M.; Sarstedt, M. PLS-SEM: Indeed a Silver Bullet. J. Mark. Theory Pract. 2011, 19, 139-152. [CrossRef]

125. Henseler, J.; Ringle, C.M.; Sarstedt, M. A New Criterion for Assessing Discriminant Validity in Variance-Based Structural Equation Modeling. J. Acad. Mark. Sci. 2015, 43, 115-135. [CrossRef]

126. Fornell, C.; Larcker, D.F. Structural Equation Models with Unobservable Variables and Measurement Error: Algebra and Statistics. J. Mark. Res. 1981, 18, 382-388. [CrossRef]

127. Henseler, J.; Ringle, C.M.; Sinkovics, R.R. The use of partial least squares path modeling in international marketing. In New Challenges to International Marketing; Sinkovics, R.R., Ghauri, P.N., Eds.; Advances in International Marketing; Emerald Group Publishing Limited: Bingley, UK, 2009; Volume 20, pp. 277-319, ISBN 978-1-84855-469-6.

128. Chin, W.W.; Dibbern, J. An Introduction to a Permutation Based Procedure for Multi-Group PLS Analysis: Results of Tests of Differences on Simulated Data and a Cross Cultural Analysis of the Sourcing of Information System Services Between Germany and the USA. In Handbook of Partial Least Squares: Concepts, Methods and Applications; Esposito Vinzi, V., Chin, W.W., Henseler, J., Wang, H., Eds.; Springer Handbooks of Computational Statistics; Springer: Berlin/Heidelberg, Germany, 2010; pp. 171-193, ISBN 978-3-540-32827-8.

129. Henseler, J.; Ringle, C.M.; Sarstedt, M. Testing Measurement Invariance of Composites Using Partial Least Squares. Int. Mark. Rev. 2016, 33, 405-431. [CrossRef]

130. Oleniuch, I.; Cichocka, I. Regional Food Products and Region-Wise Consumer Ethnocentrism. Mod. Manag. Rev. 2015, 20, 143-153. [CrossRef]

131. Baughn, C.C.; Yaprak, A. Mapping country-of-origin research: Recent developments and emerging avenues. In Product-Country Images: Impactand Role in International Marketing; International Business Ress (Haworth): New York, NY, USA, 1993; pp. 89-116.

132. Dekhili, S.; Sirieix, L.; Cohen, E. How Consumers Choose Olive Oil: The Importance of Origin Cues. Food Qual. Prefer. 2011, 22, 757-762. [CrossRef]

133. Aprile, M.C.; Caputo, V.; Gallina, G. Attitude and Awareness of EU Quality Labels: An Analysis of Italian Consumers. Riv. Econ. Agrar. 2009, 64, 269-289.

134. Bryła, P. Regional Ethnocentrism on the Food Market as a Pattern of Sustainable Consumption. Sustainability 2019, 11, 6408. [CrossRef]

135. Poon, P.; Evangelista, F.; Albaum, G. Attitudes of Migrants towards Foreign-made Products: An Exploratory Study of Migrants in Australia. J. Consum. Mark. 2010, 27, 35-42. [CrossRef] 